\title{
Philosophy of Sport from the Institutional, Content Related and Methodological Viewpoint
}

\author{
Jerzy Kosiewicz
}

Josef Pilsudski University of Physical Education in Warsaw, Poland

ABSTRACT

In this article Author presents the dispute on the philosophy of sport. He points out four standpoints concerning the existence of the philosophy of sport: a) a commonsense one, b) a content related/methodological one, c) a reductionist one, d) a nihilistic one.

The first points out that the discussed branch of science exists, that its final stabilization took place in the years 1967-1979. That opinion is proclaimed by Wojciech Lipoński (an English philologist), who is supported by Zbigniew Krawczyk (a sociologist of culture, an outstanding sociologist of sport, he dealt also with philosophical aspects of sport, 1995, 1997a, 1997b), Stanisław Kowalczyk (an outstanding catholic philosopher, he expressed his opinions also on the philosophy and theology of sport 2002, 2007). That viewpoint, according to my exploratory talks, is shared by a majority of members of the British Philosophy of Sport Association, the European Association for the Philosophy of Sport and the International Association for the Philosophy of Sport, mainly because of lack of proper preparation - that is, philosophical education.

The discussed standpoint has a commonsense character, since it does not tale into account the real level of contents of the philosophy of sport and relations taking place between it and general philosophy. It emphasizes only the first of the abovementioned requirements (the structuralfunctional one). Nobody of the abovementioned proponents of the first standpoint is aware of the need of meeting the two others of the abovementioned requirements - the content related one and the methodological one.

An exception in that respect is Rev. Stanisław Kowalczyk, who admittedly raises issues connected with those two others requirements, but the contexts of justification he has formulated have - especially in the content related respect - a commonsense character. Nota bene, statements of a similar character on fundamental issues happened even to the greatest philosophers, among others to Hegel. Moreover Kowalczyk considers also (although in a disputable way) methodological issues concerning methodological foundations of the philosophy of sport. Because of the fact that I do not agree with both content related and methodological argumentation of the great Catholic philosophers, I devote more space to a polemic against him - that is, justification of my standpoint - in the subsequent part of the text.

The second standpoint is expressed by Jerzy Kosiewicz. It is shared by, among others, Ivo Jirasek, Scott R. Kretchmar, Jim S. Perry, Arno Muller (it refers to arguments comprised in that text in part III and presented also in presence of the abovementioned persons during the conference of the 
IAPS in Olomouc in 2005). It assumes that the philosophy of sport exists, but solely in the institutional-organisational (structural-functional) sense. However, because of content related and methodological reasons, it is still in an early phase of development and hence we more have to do in that respect with philosophical reflection on sport - that is, in that case, with application of assumptions and issues from the field of general philosophy and specialized philosophies to ideography, explaining, understanding and evaluating phenomena as well as theoretical and practical activity connected with sport - than with the philosophy of sport in the strict sense of the word.

The third viewpoint suggests that the philosophy of sport has not come into existence yet. McFee in one part of his text entitled Do we need a philosophy of sport? (in: Are There Philosophical Issues Respect to Sport (Other Than Ethical Ones), 1998, pp. 3-18) undermines the sense of its existence. He wonders if it is needed at all and he proclaims, after a long argument, that it is not. He proclaims, not without a reason, that if in the process of creating the philosophy of sport we have to do solely with application of philosophy for reflection on sport, so, as a matter of fact, the philosophy of sport as such is not needed at all. The general philosophy will suffice as a theoretical foundation for reflection on sport, for explaining and understanding its sense, meaning, essence, cultural and biological background, social and psychological mechanisms, needs, motives, etc.

I suppose that working on that assumption we have to do rather with philosophical reflection on sport than with any form of the philosophy of sport. Nevertheless, the precondition of existence of the philosophy of sport in the strict sense of the word is referring to achievements of the whole philosophy. And philosophical reflection on sport is the first step on the road to creation of a fully autonomous and mature philosophy of sport.

Hence, I do not share the final McFee's conclusion included in the discussed text and proclaiming that the philosophy of sport as such is not needed, since each newly born philosophical branch goes through the application period, but, sooner or later, it breaks free from that initial content related and methodological dependence. It has also a right for its own academic name since the very beginning.

The fourth standpoint has a radical character. It proclaims categorically that any philosophical reflection on sport is unnecessary - similarly as neither the philosophy of railroading, nor the philosophy of transport as such, nor the philosophy of mining or carpentry are needed. It is proclaimed that there are such fields which may do without philosophy and which do not need philosophy for anything. They allegedly include physical activity, activity in the field of physical culture. That view is proclaimed and supported by, among others. Henning Eichberg and Ejgil Jespersen.

Author is not a proponent of that viewpoint, because physical culture and sport, among others because of their significance and range of social, cultural, health-related or axiological influences, implicate indubitably the need of cognitive studies of a philosophical character which should be continuously deepened and widened.

Defining organizational-institutional, content related and methodological deficiencies characteristic for the philosophy of sport Authors points out to barriers which must be overcome to enable its further development. It is facilitated by defining its identity. Author thinks at the first about institutional-organisational difficulties:

1. The philosophy of sport has not appeared in structures of many scientific and didactic institutions closely connected with sport.

2. Neither she is present in syllabuses and didactic of many of the abovementioned institutions.

3. About $85 \%$ of members the international, the British and the European association of philosophy of sport - as well as participants of conferences on the subject and research projects and teams - have no 
philosophical education.

4. Many former chairpersons of scientific associations in Europe and outside had no philosophical education. A majority of them played a remarkable organizational and institutional role connected with promoting and strengthening the status of the philosophy of sport. However, their activity only indirectly and insufficiently facilitated development of that philosophy in the content related and methodological sense.

5. The strictly philosophical milieu manifests poor interest in the philosophy of sport. A percentage of persons from that milieu who carry out studies connected with it or express their opinions about it are too low.

He thinks also that it is possible to distinguish the following content related and methodological deficiencies characteristic for the philosophy of sport:

1. Shortage of original assumptions and issues, which have been worked out solely on the ground of the philosophy of sport and are characteristic only for that discipline.

2. The discussed philosophy uses only languages of general philosophy and other specialised philosophies, referring to their terms, notions, categories, branches, circles, schools, currents, periods, ages, assumptions, issues, etc.

3. There is no feedback influence on general philosophy and specialised philosophies.

4. Literature on the philosophy of sport has introductory (initial) and applicative qualities.

5. Because of the abovementioned reasons, the philosophy of sport does not meet the fifth, the sixth and the seventh methodological condition concerning becoming independent from the abovementioned application and working out its own, specific assumptions and issues, as well as feedback influence. That is because such a situation makes it impossible to confirm not only its autonomy, but also its maturity.

6. Sports sciences (which, treated in a broader or different way, can be called physical culture sciences) have no common and coherent content related and methodological basis. They are very varied in that respect. It makes impossible coherent sublimation of that science in the form of the philosophy of sport. In that case, the first methodological criterion (according to S. Kamiński's interpretation), concerning its autonomy, is not fulfilled, because the subject of its interest connected with sports sciences has not been defined.

7. The fact that the philosophy of sport is not cognitively advanced (that is, there are no significant results of practising it), and that there are no means connected with the discussed activity (that is, a specialised methodology) and facilitating its development, causes that it is neither autonomous, nor mature from the viewpoint of the second methodological criterion according to Kamiński's interpretation.

8. A low level of meta-scientific self-definition of the philosophy of sport causes that the third methodological criterion according to Kamiński's interpretation, concerning self-reliance, is not fulfilled.

One of reasons of the abovementioned immaturity and lack of autonomy of the philosophy of sport is also lack of necessary research-related competences (the eighth criterion concerning specialized methodology is not fulfilled). It refers, on the one hand, to superficial and commonsense character of knowledge about phenomena and issues concerning sport - including knowledge from the field of sports sciences - and, on the other hand, to improper preparation, education and philosophical competences.

KEYWORDS general philosophy, philosophy of sport, methodology 


\section{Philosophy of sport - sources and descriptions (prolegomena)}

It is possible to distinguish the five basic sources of the philosophy of sport which were necessary for that specific form of scientific reflection to come into being. It refers to: a) facts and sports phenomena of a sensual and measurable or discretionary character - achievement-oriented ones, recreational ones and health-oriented ones; b) general philosophy and various specialised philosophies; c) general methodology and specialised methodologies connected with various forms of philosophy; and e) other specialised sciences.

Admittedly, the philosophy of sport could not come into being without any of the first four sources - and from that viewpoint they seem equally important - but in the centre of interest of the discussed form of intellectual activity there is sport and it constituted a necessary precondition of the discussed form of reflection. It is the most important objective (concerning the subject-object relation) source of that philosophy, since it constitutes its species essence - that is, such a quality which makes it distinct from other forms of philosophy. It is worth emphasizing that sport - and especially the Olympic Games as a form of religious cult - used to be an especially significant and periodical regulator of social life in ancient Greece. Those manifestations of physical and religious activity appeared considerably earlier than philosophy.

The second important source (in that peculiar hierarchy of genetic conditions) of the discussed specific scientific discipline are the abovementioned philosophies which inspired and facilitated its development. It refers - shortly speaking - to theoretical solutions, assumptions and issues from the fields of general philosophy and specialised philosophies which are used while creating foundations and shaping initial conceptions, hypotheses and theories being necessary for coming into being of, first, philosophy of sport and then of the philosophy of sport in the strict sense of the word - and for its further development.

The third source are sports sciences - basic, practical and specialist ones - which study manifestations of sports activity in an empirical and theoretical way. The philosophy of sport uses besides solutions from general philosophy and specialised philosophies - results and achievements of those sciences in the field of creation of statements, hypotheses, laws or theories of a generalizing character.

The foundations of studies in the fields of general philosophy, specialised philosophies (including the philosophy of sport) and specialised sciences are constituted by a proper methodology. It is the fourth, but an extremely important source, since it conditions proper and reliable inquiries in the field of the philosophy of sport. It is because of the fact that exploration requires application of a proper methodology - that is, suitable theoretical assumptions and general and specialised research methods.

The last source is constituted by specialised sciences. They are not - unlike the previous sources - a necessary precondition of coming into being of that philosophy, but they significantly influence its content with their results of studies. It refers to, for example, biological and social pathologies in sport. Explorations from the fields of biology, physiology of effort or medicine point out why prohibited pharmacological doping leads to destruction of the functional structure of the organism. On the other hand, psychological, sociological and pedagogical studies make it possible to come to a conclusion that forbidden doping results in smaller or greater disturbances of personality, social bonds and group relations. They generate neuroses, they may lead to mental disorders as well as to pedagogical and educational problems, which are especially harmful for children and youth.

It refers also to social sciences dealing with aggression and violence in sport. Psychological, sociological and pedagogical studies - as well as those from the field of specialised philosophies - are 
helpful in that respect and their results facilitate inquiries in the field of the philosophy of sport. A similar situation is connected with the sociology, psychology and philosophy of morality. They facilitate - in a content related sense - considerations concerning the ethics of sport.

Specialised sciences are not a primary source and they are not necessary for coming into being of the philosophy of sport among others because of that reason that philosophical reflection on sport appeared earlier (in Plato's dialogues) than specialised sciences. Till Aristotle's times philosophy had been the only science (whole science or every science). Only thanks to him a separation of the first philosophy and formal confirmation of autonomy of specialised sciences took place.

In a further part of the text I will take a position on the issues connected with the pointed out sources.

At the beginning I would like to emphasise that in spite of the fact that I have a critical attitude to the statement that the philosophy of sport exists as such - that is, that it exists as an autonomous science (or a scientific discipline or a subdiscipline of philosophy), which is mature regarding its contents and methodology - I have nothing against using the term "philosophy of sport" because of at least three reasons. Firstly, that term has been popularized and it is more convenient - among others, from the pragmatic viewpoint - than, for example, a term "philosophical reflection on sport", in spite of the fact that the latter, taking into account the real cognitive contents of that branch, is more accurate in content related and methodological sense. Secondly, because nevertheless the discussed discipline aspires for autonomy and maturity in the abovementioned respects - which sooner or (what seems more probable) later may become real. Thirdly, it is advisable to formulate and use names according to the accepted terminological convention. I mean similar cases in the past which concerned, among others, the philosophy of art, the philosophy of technology, the philosophy of physics.

\section{On the dispute over and metaphilosophical reflection on the philosophy of sport}

\section{Four standpoints in the dispute over the existence of the philosophy of sport}

There are at least four standpoints concerning the existence of the philosophy of sport: a) a commonsense one, b) a content related/methodological one, c) a reductionist one, d) a nihilistic one.

The first points out that the discussed branch of science exists, that its final stabilization took place in the years 1967-1979. That opinion is proclaimed by Wojciech Lipoński (an English philologist), who is supported by Zbigniew Krawczyk (a sociologist of culture, an outstanding sociologist of sport, he dealt also with philosophical aspects of sport,1995, 1997a, 1997b), Stanisław Kowalczyk (an outstanding catholic philosopher, he expressed his opinions also on the philosophy and theology of sport 2002, 2007). That viewpoint, according to my exploratory talks, is shared by a majority of members of the British Philosophy of Sport Association, the European Association for the Philosophy of Sport and the International Association for the Philosophy of Sport, mainly because of lack of proper preparation - that is, philosophical education.

The discussed standpoint has a commonsense character, since it does not tale into account the real level of contents of the philosophy of sport and relations taking place between it and general philosophy. It emphasizes only the first of the abovementioned requirements (the structural-functional one). Nobody of the abovementioned proponents of the first standpoint is aware of the need of meeting the two others of the abovementioned requirements - the content related one and the methodological one. 
An exception in that respect is Rev. Stanisław Kowalczyk, who admittedly raises issues connected with those two others requirements, but the contexts of justification he has formulated have - especially in the content related respect - a commonsense character. Nota bene, statements of a similar character on fundamental issues happened even to the greatest philosophers, among others to Hegel. Moreover Kowalczyk considers also (although in a disputable way) methodological issues concerning methodological foundations of the philosophy of sport. Because of the fact that I do not agree with both content related and methodological argumentation of the great Catholic philosophers, I devote more space to a polemic against him - that is, justification of my standpoint - in the subsequent part of the text.

The second standpoint is expressed by Jerzy Kosiewicz. It is shared by, among others, Ivo Jirasek, Scott R. Kretchmar, Jim S. Perry, Arno Muller (it refers to arguments comprised in that text in part III and presented also in presence of the abovementioned persons during the conference of the IAPS in Olomouc in 2005). It assumes that the philosophy of sport exists, but solely in the institutional-organisational (structural-functional) sense. However, because of content related and methodological reasons, it is still in an early phase of development and hence we more have to do in that respect with philosophical reflection on sport - that is, in that case, with application of assumptions and issues from the field of general philosophy and specialized philosophies to ideography, explaining, understanding and evaluating phenomena as well as theoretical and practical activity connected with sport - than with the philosophy of sport in the strict sense of the word.

The third viewpoint suggests that the philosophy of sport has not come into existence yet. McFee in one part of his text entitled Do we need a philosophy of sport? (in: Are There Philosophical Issues Respect to Sport (Other Than Ethical Ones), 1998, pp. 3-18) undermines the sense of its existence. He wonders if it is needed at all and he proclaims, after a long argument, that it is not. He proclaims, not without a reason, that if in the process of creating the philosophy of sport we have to do solely with application of philosophy for reflection on sport, so, as a matter of fact, the philosophy of sport as such is not needed at all. The general philosophy will suffice as a theoretical foundation for reflection on sport, for explaining and understanding its sense, meaning, essence, cultural and biological background, social and psychological mechanisms, needs, motives, etc.

I suppose that working on that assumption we have to do rather with philosophical reflection on sport than with any form of the philosophy of sport. Nevertheless, the precondition of existence of the philosophy of sport in the strict sense of the word is referring to achievements of the whole philosophy. And philosophical reflection on sport is the first step on the road to creation of a fully autonomous and mature philosophy of sport.

Hence, I do not share the final McFee's conclusion included in the discussed text and proclaiming that the philosophy of sport as such is not needed, since each newly born philosophical branch goes through the application period, but, sooner or later, it breaks free from that initial content related and methodological dependence. It has also a right for its own academic name since the very beginning.

The fourth standpoint has a radical character. It proclaims categorically that any philosophical reflection on sport is unnecessary - similarly as neither the philosophy of railroading, nor the philosophy of transport as such, nor the philosophy of mining or carpentry are needed. It is proclaimed that there are such fields which may do without philosophy and which do not need philosophy for anything. They allegedly include physical activity, activity in the field of physical culture. That view is proclaimed and supported by, among others. Henning Eichberg and Ejgil Jespersen. 
I am not a proponent of that viewpoint, because physical culture and sport, among others because of their significance and range of social, cultural, health-related or axiological influences, implicate indubitably the need of cognitive studies of a philosophical character which should be continuously deepened and widened .

\section{The dispute over philosophy as a form of metaphilosophy}

Considerations which are presented below refer to the second standpoint. It includes an attempt to answer the question: can the philosophy of sport (it refers to its achievements) be treated as an autonomous and mature discipline? Inquiries presented in the text concern not only its existence from the institutional-organisational viewpoint (nota bene its existence in that respect does not raise any doubts); they focus first of all on its cognitive status considered both from the content related as well as the strictly methodological viewpoint.

Studies on that significant issue take on a form which is significant for the philosophy of sport - namely, as it would be called by Zdzisław Kraszewski (1975, pp. 190-205), the form of a dispute with a thesis; that is, of an academic argument. That argument is important for the development of virtually non-existing - initiated only by several significant texts - self-knowledge of the field. I mean metaphilosophical reflection on qualities of the philosophy of sport (which is called later the metaphilosophy of sport).

It can be assumed that it constitutes one of forms - that is, one of subdisciplines - of general metaphilosophy. In that sense - similarly as other subdisciplines of metaphilosophy in their relation towards the connected disciplines or sciences, such as the philosophy of law, the philosophy of medicine or the philosophy of physics - it can be one of important driving forces of the philosophy of sport moving it towards the status of an autonomous science. The foundations of metaphilosophical reflection on qualities of sport - that is, of the metaphilosophy of sport - are constituted (in, among others, initiative-related, inspiration-related and consolidation-related sense - by the dispute over existence of the philosophy of sport, since the level of development of self-knowledge, metascience or metaphilosophy of sport is also an important evidence, indication of maturity of the presented cognitive field.

Both the philosophy of sport and its knowledge on itself - that is, cognitive self-reflection, metaphilosophy of sport - are at an early stage of its existence and it will not change soon (Kosiewicz, 2005a and b, 2006). However, regardless of how achievements of the philosophy of sport are perceived, a scientific argument including content related, and not persuasional, argumentation can contribute to its development. The presented text takes, first of all, that viewpoint into account. It refers to two my papers published in a journal „Ido. Ruch dla Kultury" /'Ido. Movement for Culture"/, entitled Filozofia sportu czy filozoficzny namyst nad sportem - nowe ujęcie /Philosophy of Sport or Philosophical Reflection on Sport - a New Interpretation/ (Kosiewicz 2006, pp. 306-313) and $O$ filozofii sportu /On Philosophy of Sport/ (Kosiewicz 2007, pp. 156-166). The first of them has also been published in English (in a longer and a shorter version) at the Semmelweis University in Budapest, Hungary, University of Bratislava in Slovakia (2005b) and at the University of Olomouc in the Czech Republic, as well as in Poland (Kosiewicz 2005a).

Those texts were written mainly under the influence of Lipoński's statement (unpublished) and a polemic by Rev. Stanisław Kowalczyk (2007, pp. 152-155), where he referred to my abovementioned text from 2006 (pp. 306-313). Both of them proclaim without any doubt the existence of the philosophy of sport. 


\section{The existence of the philosophy of sport from the institutional-organisational viewpoint}

The existence of a particular science - or of a connected academic discipline or subdiscipline can be regarded from the institutional-organisational (structural-functional) viewpoint.

Then, among others, we take into account its existence in the scientific, university (that is academic - in that text I will not differentiate between those two terms) milieu as a subject which meets at least three conditions. The first refers to its didactical properties. On the basis of that requirement it is assumed that the discussed subject is taken into account in the curriculum of a tertiary school - that is, it is taught, depending on a solution, in a form of obligatory lectures or seminars which possibly (together with a connected syllabus) provide knowledge required during exams.

The second condition concerns scientific studies. In that case it means, of course, strictly theoretical studies characteristic for the humanities, which are made in academic centres - among others, at general universities and at universities of physical education, as well as in strictly researchoriented institutions, such as e.g. various national academies of sciences.

The third condition is placing a given subject in the institutional-organisational (structuralfunctional) structure of a given institution - that is, of a tertiary school or of a research institution. It is about treating the philosophy of sport as a basis for functioning of a given institution of a researcheducational, educational or only research kind. It refers in a given case to, for example, a unit of philosophy of sport, a department of philosophy of sport or a proper institute or a faculty.

From the institutional-organisational (structural-functional) viewpoint, the existence of a given subject must meet at least one of the first two conditions. The third condition is insufficient for meeting the institutional-organisational assumption as a general - and, in this case, the leading principle. That is because it is not enough to appoint a body of structural properties (that is, constituting only a part of a greater institution), if there is no a didactic or a research subject a given structural unit should be connected with in the functional sense. It means that the third condition may be regarded as met when it is necessarily and indispensably connected with at least one from the first two conditions - that is, when a given unit of the philosophy of sport, a department, an institute or a faculty is connected at least with teaching or with research in a given field. The pointed out units (institutes, departments, etc.) existing in academic (university) centres in Poland and abroad usually meet both the first and the second condition.

The first viewpoint concerns existence of a definite science, a scientific discipline or a subdiscipline in the institutional-organisational (structural-functional) sense. It includes both those sciences, disciplines or subdisciplines which meet content related requirements connected with maturity and autonomy of a smaller or a greater number of methodological criteria and those which do not. It refers mainly to newly created sciences, disciplines and subdisciplines which are taught and studied by academic centres or strictly research-oriented institutions, such as the Polish Academy of Sciences or autonomous research institutes.

Hence, no philosopher of sport or philosopher dealing with issues of sport I know has ever undermined - taking into account the first viewpoint - the existence of the pointed out field of knowledge. There is no argument over that. For example, Graham McFee (the abovementioned Wittgensteinist dealing with philosophical reflection on sport), does not question its existence, in spite of the fact that he is of an opinion that actually the philosophy of sport is utterly redundant, because generally speaking - it uses only theoretical and methodological assumptions of general philosophy (of its particular branches) and of specialized philosophies (McFee 1998, pp. 3-18). 
I do not question the existence of the philosophy of sport as an academic field (and I am sure that others do not do it either), because, like others, I took active part e.g. in annual conferences and symposia of the International Association for the Philosophy of Sport, the British Philosophy of Sport Association or in philosophical session of the European College for Sport Sciences, as well as - since 2008 - in proceedings of the European Association for the Philosophy of Sport - both as the keynote speaker and as an ordinary one.

I do not question the existence of that field also because of the fact that I am connected - by participation in teaching, research and organizational activities - with international and European associations of the philosophy of sport (as a member of the board of the European Association for the Philosophy of Sport), because I have published three books just on the philosophy of sport (Kosiewicz 1986, 2004, 2006), a two-volume selection of texts in that field (Krawczyk, Kosiewicz 1990), 23 collective monographs dedicated, among others, to the philosophy of sport ${ }^{1}$ including 13 in English) and some hundred texts concerning the philosophy of sport (over a hundred in English). I wrote also its curricula. Just because of that reason I have no doubts that the philosophy of sport as a cognitive discipline exists in the institutional-organisational sense - that is, in the way which has been presented above.

That opinion is strengthened by the fact that many times I have gone as a visiting professor to give lectures on the philosophy of sport at the following universities: Univerzita Palackého in Olomouc in the Czech Republic (4 times); the Jyväskylä University in Finland (3 times); the Semmelweis University in Budapest, Hungary (4 times); the Norwegian School of Sport Sciences in Oslo (2 times); Deutschen Sporthochschule Koeln; INEF de Catalunya in Barcelona, Spain; Univerziteta Komenskeho in Bratislave, Slovakia (2 times); the Tallinn Pedagogical University in Estonia (2 times); the Lithuanian Academy of Physical Education in Kaunas, Lithuania; Universidad de Colima in Mexico; La Universidad de Gualdajara in Mexico and Universidad Iberoamericano in the Mexico City; the University of Southern Denmark in Odense and the University of Stirling in Scotland.

I have hosted also professors (some of them several times) giving lectures on the philosophy and sociology of sport, such as: Sigmund Loland, the Rector of the Norwegian School of Sport Sciences (Oslo in Norway), Ejgil Jespersen from the Norwegian School of Sport Sciences (Oslo in Norway), Henning Eichberg from the University of Southern Denmark (Odense in Denmark), Georg Anders from Bundesinstitut für Sportwissenschaft (Bonn in Germany) and from Deutschen Sporthochschule Koeln, Otmar Weiss from Institut für Sportwisenschaft der Universität Vien,

\footnotetext{
${ }^{1}$ Kosiewicz, J., Obodyński, K. (scientific editors), Sport in the Mirror of Values, Wydawnictwo Uniwersytetu Rzeszowskiego. Rzeszów 2003; Kosiewicz, J., Obodyński, K. (scientific editors), Sports Involvement in Changing Europe, Wydawnictwo Uniwersytetu Rzeszowskiego, Rzeszów 2004; Kosiewicz, J., Obodyński, K. (scientific editors), Sport and Society, Wydawnictwo Uniwersytetu Rzeszowskiego Rzeszów 2004; Kosiewicz, J. (scientific editor) Physical Activity in Integrating Europe, Wydawnictwo AWF Warszawa, Warszawa 2004; Kosiewicz, J. (scientific editor), Education through Sport: Towards an International Academy of Sport for All, International Academy of Sport for All, Kopenhagen 2004; Kosiewicz, J., Obodyński, K. (scientific editors), Axiological Dimensions of Sport - Practical Aspects, Wydawnictwo Uniwersytetu Rzeszowskiego Rzeszów 2004; Kosiewicz, J. (editor) Sport, Culture and Society, In Honour of Professor Zbigniew Krawczyk, Wydawnictwo AWF Warszawa, 2005; Kosiewicz, J. (scientific editor), Movement Recreation for All, Wydawnictwo BK, Legionowo 2006; Kosiewicz, J., Environmental Differentiations of Tourism, Kosiewicz J. (scientific editor), Wydawnictwo BK, Legionowo 2006; Kosiewicz, J. (scientific editor), Sport and Values. Theoretical Foundations, Wydawnictwo AWF, Warszawa 2006; Eichberg, H., Kosiewicz, J., Obodyński, K. (scientific editors), Sport for All as a Form of Education, Wydawnictwo Uniwersytetu Rzeszowskiego Rzeszów 2007; Kosiewicz, J., (scientific editor), Social and Cultural Aspects of Sport, Wydawnictwo AWF Warszawa, 2007; Kosiewicz, J., (scientific editor), Social and Cultural Aspects of Sport, Wydawnictwo AWF Warszawa, 2007.
} 
(Austria), Grant Jarvie from the University of Stirling (Stirling in Scotland), Bart Crum from the Free University (Amsterdam in Holland), Kimmo Suomi from the University of Jyväskylä (Finland), Gyongyi Foldesi from the Semmelweis University (Budapest in Hungary), Mait Arvisto from the Tallinn Pedagogical University (Estonia), Dušan Leška from Univerzita Komenského (Bratislava in Slovakia), Bohuslav Hodan and Ivo Jirásek - both from Univerzita Palackého (Olomouc in the Czech Republic), Saulius Kavaliauskas from the Lithuanian Academy of Physical Education (Kaunas in Lithuania). Interest in the philosophy of sport in university centres is a well-known fact.

\section{A content related viewpoint}

In considerations on the existence of the philosophy of sport out of the institutionalorganisational (structural-functional) context there appear, however, serious doubts. It refers especially to the content related and methodological status of the studied discipline. In that part of my argument I deal, first of all, with content related issues, although in some cases some arguments from that field will seem somehow related to justifications of an institutional-organisational (structural-functional) character.

\section{Literature and content related autonomy of a scientific discipline}

There exists a view assuming that in the field of philosophy there is a specialized branch called the philosophy of sport and that it functions as an autonomous branch of science. It is to be proved by, among others, abundant subject-related literature.

That standpoint is to be justified by P. Mc Bride's work The Philosophy of Sport from 1932. The final stabilization of the philosophy of sport allegedly took place in the years 1967-1979, when there came out, among others, monographs by H. Slusher (Man, Sport and Existence, 1967), P. Weiss (Sport. A Philosophic Inquiry, 1969), W. J. Morgan (On the Path toward an Ontology of Sport, „Journal of the Philosophy of Sport" 1976; Some Aristotelian Notes on the Attempt to Define Sport, "Journal of the Philosophy of Sport" 1977), H. Lenk (Social Philosophy of Athletics, 1979). I would add to that list Philosophy and Human Movement (1978) by D. Best - a widely praised monograph.

Other H. Lenk's works were papers - Prolegomena toward an Analytic Philosophy of Sport (1985), Towards a Social Philosophy of Achievement and Athletics (1988), as well as chapters in joint publications edited by him - among others in Aktuelle Probleme der Sport Philosophie (1983).

Other important works were Philosophy of Sport (1990) by D. Hyland, a highly valued handbook by R. S. Kretchmar entitled Practical Philosophy of Sport (1994) and its second edition Practical Philosophy of Sport and Physical Activity (2005).

However, that argumentation is not convincing for me, in spite of the fact that I would like the philosophy of sport - as a philosopher and a scholar considering issues of sport from the philosophical viewpoint - to come into being in the content related sense at last, to meet all suitable criteria in the fields of general methodology and specialized methodologies and to develop as well as it is possible in order to achieve the status of a mature and autonomous science (or a discipline, or a subdiscipline). It would obviously facilitate development of knowledge on sport and the development of philosophy as such.

The fact that there has appeared journals and academic organisations connected with the philosophy of sport is not enough to constitute a methodological argument supporting the thesis that 
there exists the philosophy of sport. They can only help it to come into existence in a mature and autonomous form. And it will probably happen, because contemporary science - including philosophy - is strongly institutionalized and by and large it does not exist out of institutions which have been founded to develop it, because times of David Hume or Ludwig Feuerbach, who worked far away from academic hustle and bustle, passed.

Unfortunately, it does not come from the fact that there exist "works completely presenting the philosophy of sport, which have been published as books, specialist journals dedicated to it, scientific organisations and academic handbooks, as well as its extensive bibliographies" that "the very discipline must exist", what is maintained by Lipoński in his unpublished text.

In a given case there appears confusion between the institutional-organisational (structuralfunctional) order and the content related and methodological order. Of course, taking into account the first order, the existence of the philosophy of sport is an irrefutable fact. However, it is only an initial and insufficient condition, because it is not enough for coming into existence of the philosophy of sport as a scientifically mature and autonomous discipline, because content related conditions and methodological conditions have not been met. Taking it into account, the philosophy of sport is going to be disrespected and rightly disregarded in the fields of other philosophical disciplines.

However, it is worth pointing out that even from the viewpoint of the institutionalorganisational (structural-functional) criterion any final stabilization has not taken place yet, because there is still much to do in the field of philosophy of sport at Polish and foreign universities. It is, for example, still far from maturity in that respect in many Polish tertiary schools - including universities of physical education. At many public and private universities (for example, at the Faculty of Physical and Health Education of the Rzeszów University) the discussed subject is not taken into account in syllabuses and curricula. Hence, there are not introduced connected institutional-organisational and structural-functional solutions - such as foundation of proper units, departments, institutes or faculties - in order to realize the abovementioned syllabuses and curricula. Thus, you can not say that the situation in that field is clear, stable and incontestable. The philosophy of sport at universities connected with sport arduously tries to obtain approval of its educational-cognitive status. It is not permitted, for example, during sessions of boards of physical education faculties - to supervise bachelor's and master's theses or to initiate doctoral or habilitation proceedings in that field. However it is recommendable to obey in that situation the directives concerning the second level of the Socratic dialectic method of a protreptic character, because there is included an incentive "to get rid of "ignorance" which is disgraceful for the man" (Krokiewicz 1995, p. 251).

On the other hand, when the pointed out argumentation is considered from the strictly content related viewpoint - things look quite different. Namely, the philosophy of sport still remains at the very beginning of its road in the content related and methodological sense. Probably many decades will pass before the discussed discipline - which is already existing in the institutional-organisational sense - is shaped, and many more before it is mature. Nowadays - according to my opinion - we have to do with the initial phase and further development of the philosophy of sport requires pioneering, arduous and time-consuming work in order to extract - as it was done by Socrates with the maieutic method - a new cognitive quality which has not been known up till now and which is constituted in that case by original philosophical assumptions and issues which are characteristic solely for the philosophy of sport. Of course - both in that light as well as from the viewpoint of further arguments proclaiming on the basis of several publications that "the final stabilization of the philosophy of sport took place in the years 1967-1979" is definitely premature. 


\section{General philosophy and the philosophy of sport}

It is relatively easy - because of formal and content related instruments; that is, knowledge they have - for philosophers by education to study sport. However, only few of them - taking into account the whole population of philosophers - do it. An overwhelming majority of philosophers treats persons dealing with the philosophy of sport with a pinch of salt. If philosophers deal with that issue, they treat it rather as a side occupation, which neither enhances their prestige in the philosophical milieu, nor raises the status of that milieu. Of course, it does not facilitate development of the philosophy of sport. It functions in the discussed milieu somehow like an illegitimate child.

I can mention two examples to illustrate it. The first of them concerns two my books dedicated to philosophical reflection on physical culture and sport (Kosiewicz 2000 and 2004), which were handed over, among others, to the library of the Institute of Philosophy of the Warsaw University. For some time they were there with three other my books (Kosiewicz 1997, 1998a, 1998b) in the philosophy of religion, dedicated especially to understanding and meaning of human corporeality in Christian anthropology (nota bene they were a basis for placing a note on my works in an encyclopaedia of the Polish Scientific Publishers entitled Religia /Religion/ (2002, p. 55). However, as I noticed 2007 (but maybe it happened earlier), the abovementioned two books (Kosiewicz 2000 and 2004) connected with the appearing philosophy of sport had been removed from the catalogue of the pointed out library - probably because they had not been counted among strictly philosophical publications. Nota bene, it is unknown whether the discussed books do not deserve it yet or whether they do not deserve it at all.

\section{Applicative character of the philosophy of sport as proof of lack of maturity and autonomy}

As it has been pointed out above, using the term the philosophy of sport is justified from the institutional-organisational (structural-functional) viewpoint. On the other hand, it raises serious doubts in the content related and methodological context. That is why it should be rather described as philosophical reflection on sport than philosophy in the strict sense of the word. However, in order to avoid a serious terminological split consisting in naming a given science, discipline or subdiscipline with names which are generally mutually exclusive, I will use the name the philosophy of sport even when the term philosophical reflection on sport should be used.

That philosophy as at its initial stage among others because it has an applicative character. That term - that is, "applicative character" - means solely that at the discussed stage of development the philosophy of sport - and it refers to all its achievements - only draws from general philosophy and specialized philosophies, from various branches, currents, periods, schools, trends, notions, terms, categories, issues and assumptions in order to - shortly speaking and using Kazimierz Ajdukiewicz's terminology (1985) - describe (ideography), explain (with nomotetic and nomological moves), understand and evaluate (with axiology) that all what, according to given authors, is connected with sport from their own subjective viewpoint.

In the philosophy of sport there is used and applied - of course, in a selective way - first of all already existing experience, effects of cognitive endeavours and achievements of the whole philosophy. Hence, while the philosophy of sport is being created, philosophy as such is treated according to its neo-Platonic conceptions (Domański 1996a, p. 7) - rather as "art of arts" than "knowledge of knowledges". Thus, existing traditional and contemporary philosophy is only a means used by developing philosophical reflection on sport - both in the content related and the formal (that is, methodological) sense. 
The philosophy of sport is only a recipient and applier of recognized and established results of inquiries in other non-sport fields of studies. Maturity of a given philosophical branch is recognized not only by its ability to transform and use that what has been created elsewhere, but also by the fact that a given fragment or some developing specialized philosophy brings in to general philosophy and other specialized philosophies new qualities, original assumptions and contexts of justification characteristic only for it.

In the case of the philosophy of sport the situation is quite different. For the time being it is something like a cognitive parasite. It borrows and uses everything what can be useful for it giving other forms of philosophy nothing in return, since no feedback relation - as it is understood by Leszek Kołakowski (2000, pp. 15-44, the first winner of the John W. Kluge Prize endowed by the Library of Congress, constituting an equivalent of the Nobel Prize in the humanities) - takes place. I mean relation characteristic for traditionally interpreted philosophy which takes place when philosophy not only makes use of achievements of other sciences, but also exerts its feedback influence inspiring them with its own cognitive achievements, with generalizations of a fulgurational (as it was meant by Konrad Lorenz (1977)) character and with assumptions characteristic only for it for further cognitive endeavours.

There is no such a situation like, for example, in the case of the philosophy of biology or of Ludwig von Bertalanffy's general system theory (1973, 1984), connected with the organismal conception of the human being understood as a functional structure, which has drawn a significant response in, among others, philosophical anthropology, the philosophy and the theory of medicine, and even in clinical medicine.

Inquiries into Descartes's physics (1958) have influenced significantly the philosophy of the cosmos and the connected ontology of the universe. Descartes presented a mechanistic vision of the world. He interpreted organic and non-organic beings with physical categories. He became a protoplast of physicalism characteristic for the Vienna Circle (called also the third positivism, neopositivism, logical empiricism and - by Rudolf Carnap - scientific empiricism (Carnap 1969, pp. 68, 70-79; 1973, p. 842.). Simultaneously with Thomas Hobbes, he created a biomechanistic conception of the human being (1839), which was referred to by, among others, Julien Offray de La Mettrie in Man a Machine (1748, 1984), who -similarly as many others - used inquiries connected with it for medical practice.

Cartesian philosophy of the human being constituted foundations of contemporary biomechanics, which is used in interesting ways in contemporary research in the field of movement recreation (called also physiotherapy) as well as in the theory of sport and sporting practice.

Sigmund Freud's (1982) considerations concerning psychoanalysis, which was created by him, have influenced significantly development of philosophical anthropology, the philosophy of medicine, psychological and psychiatric therapies and they contributed to the appearance of new forms of biological psychoanalysis as well as opposing various forms of culturally-oriented neopsychoanalysis, which assumed that mental disturbances, neuroses, deviations and pathologies are caused by smaller or greater disruptions of social relations. Psychoanalysis and neo-psychoanalysis have greatly enriched contemporary conceptions of the human being and medical therapies.

Freud's psychoanalysis has also been applied in the philosophy of art, the theory of literature and the theory of drama. For example, undecided, self-restricting, unfulfilled, hesitant, inconsequent Hamlet's behaviour can be - although one-sidedly - explained by referring to the Oedipus complex, which was described by the creator of psychoanalysis. After all, Hamlet comes to the Elsinore castle in order to take revenge on his uncle who has murdered his father and married his wife - Hamlet's 
mother. Hamlet gets confirmation of that fact (during the second scene of the first act) on the castle wall at night, when the ghost of the father tells him in details about the whole event, about the murder. In spite of that, Hamlet - who should have killed the uncle just after the revelation - is undecided what and how to do during the whole play, almost to the end of the fifth act. Referring to Freudian psychoanalysis makes it possible to explain that his behaviour is influenced by the Oedipus complex. Namely, in the light of that explanation, Hamlet's hesitation results from the fact that the uncle is, as a matter of fact, his ally, since he killed the man who had been Hamlet's greatest rival since his early childhood, who grabbed love of the beloved mother (Skwarczyńska 1978).

In that sphere - that is, in the field of influence of specialized philosophies on general philosophy, other specialized philosophies and other branches of science, there is a countless number of similar examples. However, they do not refer to the philosophy of sport yet.

Graham McFee in the chapter Are There Philosophical Issues Respect to Sport (Other than Ethical Ones) included in the monograph Ethics \& Sport (1998, pp. 3-18) points out that, as a matter of fact, there are no philosophical assumptions which are connected solely with or characteristic solely for research based reflection on sport (ibid., p. 6), that we have only to do with application of various philosophical ideas, various forms of philosophical reflection in order to define, explain and, first of all, understand what is characteristic for sporting activity.

Hence, he refers to his four main fields of philosophical interests: freedom of action, philosophical anthropology (or philosophy of person), normativity of rules and aesthetics, which were used by him as content related and methodological resources while he was explaining what is sport. He proclaims that such a research-oriented move do not provide any argument substantiating the thesis that the philosophy of sport exists, since, indeed, we have to do in that case with a move of a technical character, with a more or less successful attempt at application, and sport is only one of many examples which may be attributed to a given philosophical idea - even if sometimes some example from the field of sport is more suitable than others e.g. in educational process connected with defining general principles and manifestations of normativity of rules or freedom of action.

Exactly the same may be told about the issues appearing in a book by the abovementioned Slusher (1967), constituting simultaneously its table of contents: Sport and Being (subchapters: Realms of Being; Being-within-Sport; Truth of Being; Ontological Truth - Foundation of Form; Recognition of Truth in Sport; The Body of Entity; Sport and Purpose (Sport - An Awareness of Human Action; Sport as a Situation; Sport as It Is; Togetherness - as a Potential; Realisation of the Self); Sport and Meaning (subchapters: The Meaning of I; Sport - Relation and Meaning; Sport and the Symbol; Meaning of the Perceived Reality; Sport as Human Absurdity); Sport and the Religious (Ritual; Sport as Religious Symbol; Sport and Religion - as Institution; Morality and Ethics; Allowing for the Existing Morality; The Element of Silence); Sport: Existence and Decision (subchapters: Perfection in Sport; A Production of Work and Play; Freedom as a Function: A Real of Anxiety; Sport and Death).

Those issues, and the connected contents, are meant to constitute the crowning argument that the philosophy of sport, in an autonomous and mature form, has obviously already come to being. I will repeat that application of philosophical assumptions and issues for description, explanation, understanding or evaluation of sport is not enough to constitute the philosophy of sport in the strict sense of the word. It is, at its best, philosophical reflection on sport (that is, the philosophy of sport at an early stage of development). Hence, sport can be only a special case - a useful example facilitating considerations on, among others, the theory of truth, the theory of freedom, ontology, anthropology, morality, aesthetics or the philosophy of existence and tanatology (it may refer to, for example, combat sports - boxing or karate - or F1 car racing as well as himalaism considered from the viewpoint 
of borderline situation, like that of death). By the way, Ludwig Wittgenstein's favourable example in considerations on the theory of games was the game of chess.

\section{Famous philosophers' opinions on sport and the philosophy of sport}

Neither the fact that many outstanding philosophers raised issues connected with sport is an argument for the existence of the philosophy of sport. Introducing "sports metaphors and references to ancient sport (...) reconstruction of corporeal and spiritual experience which was gained by Plato thanks to his sports participation and victories and projection of that experience in his later philosophy" surely - and contrary to that what is proclaimed by Lipoński in his unpublished text - is no proof of creation and existence of the philosophy of sport, it is only trace presence of his experiences as an athlete in dialogues which were written later. Moreover, referring to sport or making use of examples taken from it is, after all, only application of sport-related subjects and not philosophy. The same refers to Hobbes, who allegedly thought that just sport (he played the game which was called royal tennis then, 1839) and singing in bed would ensure him longevity, or even to Sartre, who considered some aspects of sport quite extensively in Being and Nothingness (1956). But both in the first and in the second case those statements do not constitute the philosophy of sport yet.

The fact that many distinguished philosophers - much more than have been mentioned by me - proclaimed accidentally (sometimes in a more complex or deepened way) their opinions on sport, in not proof of existence of the philosophy of sport in its mature and autonomous form. It is only a manifestation of philosophical reflection on sport, for sport - because of more or less important reasons - occurred in the abovementioned philosophers' fields of interests and seemed them important. Then they applied their specialist knowledge to explain and understand what interested them as philosophers. An example in that respect may be an excellent and extensive study by Janusz Kuczyński dedicated to anthropological aspects of sport (considered from the viewpoint of the philosophy of man) entitled. Gra jako negacja i tworzenie świata/Game as Negation and Creation of the World/(1990, pp. 56-92).

\section{Does quantity transforms into quality in philosophy?}

Neither a sufficient argument for the existence of the philosophy of sport is constituted by a considerable number of papers and books. In the bibliography of an 1983 academic handbook on the philosophy of sport by C. Thomasa Sport in Philosophic Context there are mentioned 455 publications concerning the philosophy of sport and nowadays that number is surely greater. Does, however, quantity transforms into quality? That transformation - as the supposed chief principle of development of inanimate nature was once quite seriously discussed by Friedrich Engels (1949, p. 127, 1953, p. 244; Amsterdamski 1964, pp. 62-68). Nota bene it was pointed out many times, even in the period prone to Marxist ideology, that that principle does not come true - not only when it is referred to the philosophy of being. Harmful consequences of spreading false scientific theses were discussed by, among others, Stefan Amsterdamski (1981).

What can serve as proof of falseness of the view assuming that quantity stimulates increasing quality of the philosophy of sport is the level of education of members of the British Philosophy of Sport Association, the International Association for the Philosophy of Sport and the European Association for the Philosophy of Sport. About $85 \%$ of them have no philosophical education. It refers also to persons who performed highest functions in those or national associations. Both those persons as well as philosophical associations or journals on the philosophy of sport they were in charge of 
have surely played an important role in development of the philosophy of sport, first of all in the institutional-organisational sense. They supported also content related and methodological development by inviting philosophers in the strict sense of the word - such as, among others, Hanna Hogenova (Charles University, Prague, the Czech Republic), Graham McFee (University of Brighton, UK; California State University) Ivo Jirasek (University of Olomouc, the Czech Republic), Lev Kreft (University of Ljubljana) or Maria Zowisło (Academy of Physical Education, Kraków, Poland for cooperation in associations, writing for joint publications and journals and presentations as keynote speakers. However it is not enough, because the quality of works on the philosophy of sport was determined mainly by those $85 \%$.

It is possible to speak in that case about transformation of quantity into quality, but only in a quite specific and paradoxical sense. Namely, in that situation quantity stimulates poor quality, lack of philosophical competences causes that texts which are poor from the content related and methodological viewpoints are written. Often it is difficult to find any philosophy in them.

Moreover, not all of those who participate in international and national philosophical life are creative. Admittedly, subject matter of publications is varied. But only a part of them is on a quite good, good or very good level. Moreover - similarly as in the case of the rest of publications - almost $100 \%$ of them are applications, such as e.g. Stanisław Kowalczyk's monograph Elementy filozofii $i$ teologii sportu /Elements of Philosophy and Theology of Sport/ (in that case, we have to do with application of Catholic personalism. It happens, admittedly, that single texts or monographs are mature, but the philosophy of sport as such is still far from maturity and autonomy. Such a situation will last for quite a long time, because the philosophy of sport is dealt with by a relatively small - in comparison with the whole philosophical milieu - group of persons. They usually are not - apart from few exceptions - philosophers recognized by the milieu; that is, good philosophers. Those few situate considerations on sport far away from the main current of their inquiries. In the philosophical milieu the philosophy of sport is looked at as an illegitimate child and philosophers taking up studies on sport are looked at suspiciously or with a pinch of salt. It does not facilitate development of philosophical reflection on sport.

It happens also that the scientific level of a presentation is high, but, unfortunately, it is too non-philosophical. I mean that in analytical and synthetic, oral and written presentations even by persons who are outstanding regarding organizational and creative (writing) activity there dominate contexts of justification referring more to sports sciences than to philosophy. While explaining phenomena and research problems concerning sport they usually use non-philosophical terms, notions, categories, hypotheses and theories. There appear valuable texts, but not philosophical ones. The philosophy of sport as such will not appear if theoretical and practical facts concerning sport are regarded with a language characteristic for a widely understood theory of sport or, more generally, sports sciences. What is necessary in that case is philosophical language and knowledge of philosophy. There appear references to philosophy in the discussed texts, but they have rather an illustrative and superficial character.

On the other hand, it is an exaggeration to dedicate almost the whole text in the field of the philosophy of sport to inquiries into other philosophical branches. An example in that respect can be a paper by McFee entitled Paradigms and Possibilities: Or, Some Concerns for the Study of Sport from the Philosophy of Science (2007, pp. 58-77) and Searching for Truth in Sport and Exercise Sciences (2006, pp. 65-70). He generally presents there a lecture on the philosophy of sciences, methodology of empirical sciences or science studies concerning first of all Karl Popper's and Thomas Kuhn's views (unfortunately, Imre Lakatos, Paula Fayerabend or Leonard Nelson are not taken into account). Admittedly, it has a professional character, but only in a didactic - popularizing - sense. It seems 
meant for doctoral students preparing for general methodology or methodology of empirical sciences exams. That kind of descriptive presentation of Popper's or Kuhn's views would not have aroused interest even when the great thinkers were still alive, since it does not give any new research insights into them. And attaching some reflections on sport to it seemed an artificial and contingent move.

One of the past President of the IAPS behaved in quite a different way. This President bases the innovative idea pointing out that sport is philosophy (Sport as Philosophy. Presidential Address to the IAPS 2007, unpublished) on a balanced - although superficial - context of justification - including arguments both from the field of general philosophy (history of philosophy) and philosophical reflection on sport. That harmony is praiseworthy, but the pointed out factual justification appeared to be utterly mistaken. It probably results from lack of thorough philosophical education.

It is pointed out by, among others, a failed attempt at formulating a definition (referring to a not very good handbook) and then by an interpretation of the notion of philosophy allegedly characteristic for ancient Greece. In the paper was proclaimed that "the Greek term 'philosophia' literally means "love of wisdom"”. It refers in that context to Pythagoras and Socrates, who according to the author's opinion - ,made this conception of philosophy famous”. And nothing more about it, what is a pity, because author might present and discuss definitions of wisdom and definitions of philosophy by, among others, Pseudo-Plato (1973) and neoplatonic definitions of philosophy referring also to Aristotelian heritage (Domański 1996, p. 7). For example, by reading Pseudo-Plato's Definitions you can find out that fileo means desire, striving and love for sofia - that is, wisdom and knowledge (which in his times were still notions of identical meaning). That kind of deepening knowledge could contribute to formulating a different line of argument, closer to Greek antiquity.

Moreover, the author of the discussed Address - written at the end of this presidency of the International Association for the Philosophy of Sport - proclaims that when relations between sport and philosophy are considered, you can "argue that historically and ideally sport is a form of philosophy” and, moreover, that „Greek athletics and philosophy both seek knowledge in similar ways and for similar reasons" (Read 2007, p.1).

Author confirms also in Conclusion that there is no doubt that there is "resemblance between sport and philosophy” and that she understands ,sport as a truth-seeking practice analogous to philosophy, ibid., p. 9.).

Then, summing up the whole line of her argument, author argues that ,sport and science are both descendants of ancient Greek athletics. As sport philosophers we may preserve the social and educational value of athletics if we learn to see sport as philosophy" (ibid., p. 9). Nota bene, author does not mention how creation of philosophy and then of specialized sciences was influenced by culture, developing civilization, practical abilities other than sport and cognitive qualities included in art, religion or commonsense thinking. A statement proclaiming that sport is a form of philosophy cannot be sustained, because just as well you could treat as philosophy all other forms of physical activity of an autotelic or instrumental character (for example, those changing nature, society or the human individual). Shortly speaking, physical activity is not philosophy. Manifestations of theoretical activity which have not a philosophical character are not philosophy too. Only a highly sublime and specialized theoretical cognitive activity can be philosophy.

Moreover, two premises, emphasized in the text and pointing out that: a) wisdom and knowledge were a basis for Socrates's moral philosophy, and b) it is possible to find educational elements in sports activity, do not substantiate a conclusion that sport is philosophy (it is an example of a defective hypothetical syllogism). From that viewpoint, all human activity having some educational qualities would be philosophy. By the way, it is pedagogy which deals with education. 
Philosophy and pedagogy are two different specialized disciplines. Equating education - which is a part of pedagogy - with philosophy is a mistake.

\section{Does handbooks on the philosophy of sport are proof of its development?}

I am not convinced by referring to academic handbooks concerning the philosophy of sport, which are supposed to constitute an irrefutable proof that the philosophy of sport has come into existence in a form which is deepened in methodological and content related sense. I have a quite opposite opinion in that respect. Just those handbooks - more than any other publications connected with the philosophy of sport - paradoxically emphasise maybe not so much its non-existence, but its very low, often non-professional level and superficiality.

They present the philosophy of sport in the worst possible way, since they are saturated with retrospective element referring to other books trying to associate philosophy with sport. They present in a condensed form effects of other authors' studies - that is, results of application of philosophy to presented issues concerning the philosophy of sport. In comparison with other publications, they are solely secondary discussions and not source books - they are derivative in their relation towards others, but even those others contain philosophical applications and not philosophy in the strict sense of the word.

In the abovementioned paper by McFee, the author proclaims that the discussed discipline does not exist (in the content related and methodological sense - my interjection, J.K.). Moreover, nothing suggests - according to his opinion - that it is going to come into being. Hence, he is of an opinion that there is nothing to justify - both in the formal and the content related sense - writing handbooks or founding educational institutions dealing with teaching that philosophy.

That conclusion seems to me too radical. Each advanced scientific discipline had had its initial period before it developed and gained autonomy in the methodological and content related respect.

\section{Can one book be proof of existence of a mature and autonomous scientific discipline?}

On the other hand, Zbigniew Krawczyk informs in one of his unpublished texts on the philosophy of sport that its beginnings may be dated back to the 60 . of the previous century, and the abovementioned book by Slusher Man, Sport and Existence (1967) may be regarded as a work symbolizing that fact. That argument does not seem convincing either if it is confronted, for example, with Aristotle's (1988), Pomponazzi's (1980) or Descartes's (1986) works. The first of them in antiquity, the second in the $15^{\text {th }}$ century, and the third in the $17^{\text {th }}$ century wrote excellent anthropological monographs dedicated to the human soul, self, consciousness, or the psyche ( $O$ duszy /On Soul/, 1988, and O nieśmiertelności duszy /On Immortality of the Soul/, 1980, as well as O namiętności duszy /Soul's Passion/, 1986). However, it does not come from that at all that as early as since the publication of those books it had been possible to talk about the existence of psychology, which, after all, appeared much later. The abovementioned ones - similarly as many other authors (beginning from Orphicists and ancient philosophers including Christian ones, through medieval thinkers to modern writers) may be pointed out as only protoplasts of that fascinating science. The situation of the philosophy of sport is similar - in its autonomous and mature form it will probably appear much later.

Krawczyk's conclusion concerning the book by Slusher raises also doubts because of another reason. If he has known about its existence for such a long time (after all, the book was published in 1967) and evaluated it so highly that he even recognized it as a groundbreaking work constituting 
proof of existence of the philosophy of sport, why did some decades after publication of that work he supported and identified with a paper Filozofia sportu czy filozoficzny namyst nad sportem /Philosophy of Sport or Philosophical Reflection on Sport/ which three times was also signed by him with his name and which pointed out that in that respect we have to do rather with philosophical reflection on sport than with a philosophy of sport in the strict sense of the word?

\section{Does the philosophy of sport is a part of philosophy as such or a part of sports sciences?}

The philosophy of sport conceived as a part of sports sciences is not going to appear earlier than sports sciences - admittedly, continuously developed and modified - will start to exist in a mature and autonomous form. It is because of the fact that the philosophy of sport - similarly as each philosophy of a specialized discipline, like e.g. the philosophy of law, the philosophy of art, the philosophy of physics, the philosophy of biology or the philosophy of medicine - is, first of all, a part of the specialized discipline it comes from, and not a part of general philosophy. Of course, general philosophy plays - because of application-related reasons - an important role in creating specialized philosophies. Nevertheless, the philosophy of a given discipline expresses that what is characteristic for a given discipline, branch or science. That is, among other things, what makes it different from general philosophy and other types of specialised philosophies (like, for example, Kant's philosophy, Hegel's philosophy, ancient Greek philosophy or philosophy of French Enlightenment). It is, however, true that it corresponds to general philosophy (and its branches, and other specialized philosophies) just because of the fact that that what is general - terms, notions, categories, issues or assumptions has been used for creation of a given specialized philosophy. It is also true that specialized philosophies may undergo sublimation going so far to make them simultaneously a part of general philosophy.

By the way, in philosophy as such there is always a debate during conferences and in specialist journals concerning a dilemma: is philosophy science at all? That dispute is very inspiring from the epistemological viewpoint, because it serves deepening philosophers' reflection on their own discipline and facilitates determining its identity. It refers also to the philosophy of sport. The dispute includes attempts at answering the question: has the philosophy of sport already come into existence as an autonomous and mature discipline in the content related sense or do (and why do) we still need to wait for it?

Moreover - in the light of the abovementioned dispute - there is also possible a polemic concerning the question: can we call the philosophy of sport, when it is already an autonomous and mature discipline, a science or cannot we?

\section{Can lack of contents and sense in the philosophy of sport be an argument supporting} the thesis about its existence?

Paradoxically, scepticism about existence of the philosophy of sport expressed in texts dedicated to it can be surely recognized as a manifestation of epistemological activity in that field. Criticism of cognitive qualities of the discussed discipline, cautious attitude towards attempts at creating a philosophy of sport or their negation including a proper context of justification point out to and simultaneously define conditions of its identity.

Nota bene, the dispute on the existence or non-existence of the philosophy of sport can be also solved in another (however, illusory) way, which is presented below. 
It can be assumed - as it has been announced by the above subtitle - that, having made some philosophical (but non-formal) assumptions, even reflections without mature, proper, matter-of-fact qualities characteristic for philosophy and identified with it, are philosophy in the strict sense of the word. It is a typically eristic move giving versimiltude to seemingly content related qualities and providing that something what is not philosophy yet can be regarded as philosophy.

At the beginning of that line of reasoning there arises a question: is philosophical reflection on sport philosophy in the full meaning of the word or not? It can be assumed, on the basis of the below argumentation, that if we have to do with strictly philosophical reflection, it is permissible to proclaim - in spite of justified criticism - that we have, after all, to do with philosophy as such.

It refers - firstly - to philosophy in the form of thinking thought, which presents itself as well as expresses and objectivizes solely human abilities and cognitive qualities. It appears, for example, in Descartes's meditations, who presents only his own views worked out by himself, which do not come from any other supernatural sources and inspirations.

Secondly, it refers to the thought thought by the human being, coming from a transcendental (abstract and non-religious) or transcendent (religious) - so, in both cases, ideal and supernatural reality. It objectivizes itself in the subject independently from it - as it is assumed by the Hegelian conception of the Absolute, which realizes itself in the individual and collective consciousness. In the Absolute's hands the human being is a tool unaware of his role or a medium which only transmits knowledge which has come into existence and was revealed in him. He is not aware that it is not he who thinks. He does not know that the Absolute manifests itself in his thoughts, that wisdom and logic of the Absolute objectivize themselves in his views.

A similar situation takes place in the case of collective consciousness. People are sure that it is created by them; that culture, art, morality, religion, state, philosophy are their unique species quality, whereas manifestations of both collective and individual consciousness are only a product of the Absolute's necessary self-creation and self-affirmation - and not of human activity.

Thus, it can be assumed - taking into account the two abovementioned conceptions of philosophizing - that every reflection revealing itself in their fields is philosophy, since philosophical reflection - meeting methodological and content related requirements concerning institutional and non-institutional philosophy and objectivised in an oral or a written form - is philosophy. That is why you can be of an opinion that philosophical reflection on sport is philosophy, because philosophy as such has focused its attention on sport in that case. Thus, it is permissible to proclaim that we have to do with the philosophy of sport even when the philosophy of sport has not come into being in a content related and methodological sense yet. However, from the viewpoint of philosophy, in order not to introduce a paradox and, at the same time, an ontological dissonance concerning simultaneous existence and non-existence of the philosophy of sport, it is better to use a notion of philosophical reflection on sport.

To my surprise that typically eristic reasoning (Kosiewicz, 2006, pp. 310-311) has been incautiously interpreted by Kowalczyk as substantiating the existence of the philosophy of sport. He proclaimed: "that the Warsaw philosopher in his further considerations is not, however, so firm " (Kowalczyk 2007, p. 154).

I would like to proclaim that neither earlier, nor later I was more or (all the more) less "firm" as it is written by my friend from Lublin - in that respect. Probably he did not notice that my statement including a proposal of possible solution of the dispute on the existence of the philosophy of sport as a fully autonomous discipline or as only philosophical reflection on sport, was, as a matter of fact, an innocent and modest joke perversely disguised as philosophical seriousness (Kosiewicz 2006, pp. 310- 
311). The point is that if it is assumed that philosophy has an anthropogenetic character (and not an objective one as it was in Hegel's case), every philosophical reflection - including that focused on issues of sport - is philosophy. Of course, from that anthropogenetic viewpoint you can confirm the existence of the philosophy of sport regardless of the fact of meeting by it any content related and methodological conditions (including those by Stanisław Kamiński, which are not very successfully referred to by Kowalczyk). Taking into account only the anthropogenetic criterion, even a philosophical nonsense said by a philosopher can be treated as general philosophy or a philosophy of something. Hence, of course, the attempt at settling the dispute which has been announced at the beginning does not settle anything.

It may be also added that philosophy as such - that is, philosophy in the form of thinking thought in Descartes' case and of thought thought in Hegel's case - surely meets, taking into account its contents and sense, the content related criterion and the methodological criterion. Thus, from that viewpoint, the existence, maturity and sense of philosophy as such are determined by its contents and sense. Hence, the institutional-organisational (structural-functional) criterion is meaningless. The same refers to the philosophy of sport. The existence of the philosophy of sport, its autonomy and maturity are determined, first of all, by its contents and sense - and not by institutional-organisational or structural-functional qualities.

\section{Methodological and content related viewpoint}

\section{Criteria of general and specialised methodology}

Elaboration of my methodological viewpoint has been contributed to by the abovementioned polemical paper by Stanisław Kowalczyk (2007, pp. 152-155), and especially by Stanisław Kamiński's views. Rev. Kowalczyk referred to them in order to substantiate argumentation concerning the existence of the philosophy of sport as an autonomous scientific discipline (Kowalczyk 2007, p. 152, Kamiński 1992, p. 253.). That move - according to my opinion - did not have a positive result (Kowalczyk 2007, s. 152-155). Nevertheless, the discussed text has contributed to new reflections and conclusions and, as a result, to fuelling the dispute on the existence of the philosophy of sport regarded from the viewpoints of general methodology and its specialized methodology, because it seems that doubts expressed in that respect can be justified.

Kamiński writes (I quote after Kowalczyk, 2007, p. 152), that „The autonomy of a scientific discipline is determined by among others: 1 . Its subject, 2 . The level those who practice it, its means and results are on, 3. The level of its meta-scientific self-determination and 4. Its organizational and informational status /an external factor/" (Kamiński 1992, s. 253).

Three of those criteria - the first, the second and the fourth - refer directly to the discussed autonomy, whereas the third criterion refers to maturity of the scientific discipline. It is a criterion which, admittedly, determines coming into being of autonomy, but which, first of all - if the pointed out meta-scientific self-determination appears - is proof of maturity of a given discipline.

Hence I would like to emphasise that - from the viewpoint of general methodology - the philosophy of sport do not meet $75 \%$ of formal conditions (that is, three of them) pointed out by Kamiński, which are necessary for autonomy of a scientific discipline - the first condition, the second condition and the third one.

Apart from that, it does not meet four additional - and equally important - criteria determining autonomy of a scientific discipline (including autonomy of the philosophy of sport). It refers to the 
following criteria: 5. The fifth one connected with necessity of making it independent from application of basic assumptions, issues and theories characteristic for general philosophy (its branches) and specialized philosophies as main sources of its development, 6 . The sixth one pointing out that a condition necessary for the abovementioned independence is working out by a given discipline its own specific assumptions, issues and theories which have not been borrowed, 7. The seventh one concerning feedback influence creatively inspiring general philosophy (and its branches) and specialized philosophies - confirming not only autonomy, but, first of all, maturity of a given discipline.

Neither the philosophy of sport meets the eighth criterion from the area of specialized methodology connected with it - that is, a condition concerning research competences in the field of sports sciences and competences concerning philosophical instruments necessary for matter-of-fact practicing the discussed discipline. I will refer to that criterion - as well as to the first methodological criterion according to Kamiński's interpretation - at the end of presented reasoning.

For philosophy, which not only in Pseudo-Plato's times was understood, among others, as desire, striving and love for wisdom and knowledge (which once were treated as identical notions, Domański 1996), the problem of autonomy and maturity of philosophy (including the philosophy of sport) making the subject as close to the epistemological Absolute as it is possible for the human being, constitutes an issue of primary importance (Domański 1996, p. 7, Pseudo-Platon 1973).

Determining the level of autonomy and maturity of a given scientific discipline can be helped with, among others, methodological criteria - first from the area of general methodology and then those taken from its specialized methodology. In that respect, similarly as in formal disciplines, a zeroone criterion pronouncing truth or falseness is applied: either a given scientific discipline is autonomous, or it is not. There are no intermediate situations - unlike in morality, customs-related behaviours or in the penal code, where intermediate situations between good and evil are perceived. Either a fish is fresh, or it is not. There is no, say, fish of second freshness like that from "The Master and Margarita" by Mikhail Bulgakov. If a given scientific discipline do not meet at least one methodological criterion connected with autonomy, it is neither autonomous, nor mature. If it does not meet at least one criterion of maturity, it is not mature.

\section{Identity of the philosophy of sport and its autonomy}

The philosophy of sport does not meet the third criterion of autonomy of a scientific discipline pointed out by Kamiński. Namely: the philosophy of sport - apart from the few abovementioned texts (e.g. McFee 1998, Kowalczyk 2007, Kosiewicz 2006, 2007) - have no meta-scientific selfdetermining reflection. Almost all statements about the philosophy of sport have, principally, a commonsense character. Within general philosophy or systemic philosophy such situations happen too, but much more rarely. It refers even to genial thinkers, who would have never expected to be accused of it. By the way, even George Wilhelm Friedrich Hegel's views concerning the existence and qualities of time were rightly described by Martin Heidegger as "understanding time in a commonsense way" (1994, p. 601).

The abovementioned deficit of meta-scientific reflection is not only proof of lack of autonomy, but also of lack of maturity of a given discipline.

\section{Content related and methodological dependence}


The philosophy of sport is still completely dependent on content related and methodological achievements of general philosophy (and its branches) and of specialized philosophies (the fifth criterion is not fulfilled). It is a methodological fact of primary importance.

\section{Literature and the methodological criterion of autonomy}

You can also have - regardless of a great number of monographs and papers in the field of philosophy of sport - justified reservations connected with the second criterion of autonomy. The point is that the discussed philosophy is still at the beginning of the road, at the initial stage, without its specific assumptions and issues it has worked out and deepened by itself. It is not advanced yet and will not be for a long time - and possible maturity and scientific self-knowledge will appear much later. A great number of publications does not mean that quantity transforms into quality. For example, in post-Enlightenment France influence of the Catholic Church was considerably diminished. In spite of that, in the $20^{\text {th }}$ century just in France - and not in any country which was still saturated with Catholicism, we had to do with a quantitatively and qualitatively unusual abundance of excellent Catholic philosophers, such as Ettienne Gilson, Jacques Maritain or Gabriel Marcel.

\section{Application and lack of feedback}

The philosophy of sport is not a mature discipline (and hence it is not autonomous), because it does not exert inspiring and creative feedback influence on general philosophy (with its branches) and other specialized philosophical disciplines (the sixth and seventh criterion are not fulfilled). Nota bene, a term "autonomous science" does not mean at all - also when referred to the philosophy of sport - a completely autarchic science. The philosophy of sport will be fully autonomous and mature not only when it becomes relatively independent from assumptions or issues characteristic for general philosophy and specialized philosophy. It will be fully autonomous and simultaneously mature when it has created also its own - that is, not borrowed in the fundamental sense - theories, assumptions, issues and when it exerts its inspiring and creative influence on, among others, other philosophical inquiries (Kosiewicz 2006a, pp. 307-308).

\section{Universals and the philosophy of sport}

Methodological controversies (referring to the unfulfilled second and third criterion) are aroused by Rev. Kowalczyk's conclusion concerning universals which are connected with sport. He proclaims that "the philosophy of sport has a subject, which is characteristic for it - among others, universal elements and functions of sport which are not considered by any other philosophical discipline" (Kowalczyk 2007, p. 153). Their existence is to prove development of the philosophy of sport, development of its identity - that is, meta-philosophy. I am not convinced because of at least three reasons:

a) it is doubtful to proclaim that the existence of universals is to be proved by a connection with universal human attributes, such as corporeality, mentality, rationality, freedom, creativity, being susceptible to higher values or ability to live social life. There is nothing in that thesis what could legitimize universal qualities of sport as a specific kind of effort or a specific form of cultural-biological activity (nota bene, writing about effort I take into account both movement activity characteristic for a majority of sports and mental activity connected 
with bridge or chess), because the fact that the human being is an incarnated being, mental being, etc. is neither an essential, nor universal feature of sport - similarly as breathing before, during and after physical effort is neither unique, nor universal feature of sport. There is nothing specific for sport in it. It is only one of main preconditions of maintaining the human subject alive.

b) Rev. Kowalczyk's statement (2007, p. 153) is also a polemic against my text concerning universals in sport (Kosiewicz 2004c, pp. 113-118, Kosiewicz 2004b, pp. 225-236 plus edition in English in Slovenia). However, I have not found there any counterarguments put forward against those convincing - although, controversial - arguments I placed in the chapter of the pointed out book (Kosiewicz 2004b, pp. 225-236).

Nota bene, my papers quite often are deliberately controversial, because I question interpretative stereotypes which are established in commonsense thinking. It refers not only to the issue of universals, but also to negation of existence of the philosophy of sport as such (in the content related and methodological sense), negation of the opinion assuming that the Olympic Games are something more than sport or the opinion that the principle of fair play is the highest value of sport and Olympism. It refers also to rejection of the idea of existence of free time and holistic messages of Olympic education or negation of the IOC's financial disinterestedness and about the lack of the knowledge of the hypothesis and its place in the research procedure. It concerns the investigators connected with sport sciences and nature sciences too.

c) it is not true that in the chapter entitled Sport i powszechniki - od nominalizmu do aleatoryzmu /Sport and Universals - from Nominalism to Aleatorism/ (Kosiewicz 2004b, s. 225-236) I question existence of universal qualities of sport at all. The title - and especially the contents - suggest may be not something completely different, but at least quite different. Namely, I proclaim that it is possible to find one universal feature of sport. It is aleatorism. Moreover, in two more chapters - Widowisko sportowe $w$ świetle aleatoryzmu - state $i$ przypadkowe elementy struktury spektaklu/ Sports Spectacle in the Light of Aleatorism Constant and Accidental Elements of the Structure of the Spectacle/ (Kosiewicz 2004e, pp. 373-382, plus edition in English in Rome materials), as well as partly in Struktura widowiska sportowego /Structure of the Sports Spectacle/ (Kosiewicz 2004d, pp. 351-372) - I explain what aleatorism is.

Nota bene, under the influence of new reflections - among others, those connected with preparing the presented text - I have come to a conclusion that aleatorism is not an essential feature connected solely with sport, because it is a quality characteristic for the whole organic and non-organic world, for all forms of movement and intellectual activity, except of those which are based on formal rules of a mathematical and logical character. Aleatorism can be perceived, its assumptions can be also used in sport. Because of the fact that there are no issues and assumptions of a universal character specific solely for the philosophy of sport, the second and the third criterion are not fulfilled.

\section{Towards the own specialised methodology}

I agree with Kowalczyk's obvious conclusion that generally only the philosophy of sport (with some abovementioned and possible exceptions) considers issues connected with sport on philosophical ground. It does not mean, however, that it is an autonomous and mature discipline. It is unintentionally confirmed by the Lublin philosopher, when he suggests that it should - while working 
out its own specialized methodology - draw from achievements of natural sciences and the humanities; that is, from the sociological-phenomenological method, from the method of introspection taken from psychology, from the hermeneutical method and, first of all, from "the method of classical philosophy", which - according to his opinion (what sounds rather ideologically that rationally) - is "the proper method of the philosophy of sport" (Kowalczyk 2007, p. 153). Moreover, the Catholic thinker adds that "contemporary philosophy of sport should draw not only from classical (that is, Catholic) philosophy inspired by Aristole's thought, but also from other philosophical currents: linguistic philosophy, hermeneutics, phenomenology, philosophy of dialogue, philosophy of values" (ibid.).

The author of these quotations do not describe specialized methodologies (and their results) currently applied in the philosophy of sport - in that respect, especially literature in English is worth going through. He suggests only in a vague way what methodological instruments it can use in the future drawing from achievements of general philosophy and some specialized sciences (ibid.).

Thus, Kowalczyk presents only an applicative proposal (the second, third, fifth, sixth and seventh criterion are unfulfilled), confirming simultaneously that the philosophy of sport is only at the initial stage of development, that it should begin efforts to work out its own method. Hence, it is far from autonomy, not to mention maturity (Kowalczyk 2007, p. 153).

The Catholic philosopher writes that "the proper method of the philosophy of sport in the method of classical philosophy" (ibid.). That statement questions again status of the philosophy of sport as an autonomous discipline (the fifth and the sixth criterion are unfulfilled). It does it because, first of all, he does not call for working out its own specialized methodology - he recommends application of that which already exists. Secondly, that proposal may change the philosophy of sport into some extension of classical (that is, Catholic) philosophy.

\section{Philosophical currents, quantity and quality}

Singling out a few currents within the philosophy of sport - such as the liberal-Anglo-Saxon one, the Olympic and neo-Olympic one, the neo-Marxist one, the personalist one, the functionalpragmatic one and the oriental one (Kowalczyk 2007, pp. 153-4) - is not a convincing move and a sufficient argument for a high content related level, maturity or autonomy of the discussed philosophy. These are not names or number of singled out currents which are proof of the level of the philosophy of sport, but only its contents. Poor contents and small size of the existing philosophical inquiries are not going, after all, to change under the influence of more or less justified divisions or classifications. That moves are not going to make the philosophy of sport more autonomous or more mature. It is not going to undergo a qualitative change and it is not going to grow - similarly like the cake in a popular joke, which the abovementioned classifying move inevitably reminds. The blonde from the joke, who has ordered the cake, is asked how many pieces should it be cut into - six or twelve "Six" - she answers. - "I wouldn't manage to eat twelve".

\section{Does existence of the philosophy of Olympism determine the existence of the philosophy of sport?}

Proof of existence of the philosophy of sport is also allegedly constituted by existence of the philosophy of Olympism. The Catholic philosopher refers in that respect to a monograph by an excellent Cracow philosopher Józef Lipiec. Filozofia olimpizmu /Philosophy of Olympism/(1999). It is not, however, a sufficient argument, because the valuable book by Lipiec, which has been discussed 
by me at least two times (Kosiewicz 1999a, 1999b), similarly as English language works in the field of philosophy of Olympism, has an applicative character (the fifth criterion is not fulfilled). Nota bene, I have at my disposal proper subject-related materials and a bibliography received from a former President of IAPS, Heather Reid. I recommend also one of issues of Journal of the Philosophy of Sport containing articles dedicated to the philosophy of sport and suitable bibliographical information (JPS 2006).

However, it is not "abundant literature on the subject" Kowalczyk informs about (the second criterion is not fulfilled) - unless he refers to some specific, ascetic definition of abundance I do not know yet.

\section{Branches of philosophy and the philosophy of sport}

Kowalczyk - while writing on the philosophy of sport - proclaims also that ,a pragmatic argument for autonomy of that discipline is the fact that there are distinguished components of its structure - thematic blocks, such as ontology of sport, social dimension of sport, ethics of sport and aesthetics of sport. They constitute integral and developed elements of philosophical reflection on sport and that is why we can already talk about the philosophy of sport as one of philosophical disciplines" (Kowalczyk 2007, p. 154). However, ontology, ethics or aesthetics of sport do not constitute yet developed branches of the philosophy of sport (the second criterion is not fulfilled). We still have to do with initial application of basic branches of general philosophy in that respect (the fifth criterion is unfulfilled). Nota bene, Kowalczyk does not mention of e.g. axiology, epistemology, philosophical anthropology or social philosophy connected with sport. And a thematic block called „social dimension of sport" is not any branch of the philosophy of sport after all. There is not any inspiring and creative feedback influence on branches of general philosophy either (the seventh criterion is not fulfilled). That all - and the fact that we have to do with so-called thematic blocks and not with developed branches - prove clearly that the philosophy of sport lacks autonomy and maturity.

The philosophy of sport - as I have already pointed out at the beginning of the text - meets only the organizational-institutional (structural-functional) condition; hence, it exists only as an academic discipline of didactic-scientific character using the name "the philosophy of sport". On the other hand, it does not meet a majority of methodological criteria and that is why it - unlike the abovementioned ones - is still a specialized philosophy at the initial phase of development. Hence not only because of methodological reasons, but first of all because of the content related one - it is rather on the level of philosophical reflection on sport than that of the philosophy of sport in the strict sense of the word, of an autonomous and mature discipline.

\section{Sports sciences and content related/methodological coherence}

Lack of autonomy and immaturity of the philosophy of sport may result from two more significant reasons - the first one has an objective character, whereas the second is subjective. Both of them refer to content related reservations having their implications in the field of specialised methodology concerning the discussed discipline,

a) sports sciences do not constitute a coherent - in the content related and methodological sense - set of disciplines (the first criterion according to S. Kamiński's interpretation remains unfulfilled). The feature which distinguishes them is less or more direct interest in phenomena and issues connected with sport. There is no similar coherence e.g. in the case of sciences of man. There are a lot of them, they are various, they come, for example, 
from empirical sciences and the humanities, they have biological and social qualities, they are - to a smaller or a greater degree - mediated through formal sciences, they have theoretical and practical, basic (autonomous) and service, basic and applicative (with postulative aims) character. There is also possible to distinguish among them pure sciences and applied sciences, sciences and abilities, sciences and technologies. They - that is, sports sciences, similarly as sciences of man - have various aims, use various and non-coherent (in the formal sense) or even mutually excluding specialized methodologies, various terminologies, notions, categories, hypotheses and theories.

Representatives of natural, and especially biological, sports sciences cannot understand the sense of existence of the humanities - including those dealing with sport (or physical culture) - which do not use empirical methodology based on experiment and observation. Prof. Marek Kłossowski (a physiologist) was clearly surprised and astonished by the fact that that kind of sciences exists at all.

Sports sciences are a mixture of various and different disciplines, which came into being not a long ago and are at the initial - and, simultaneously, applicative - stage of development, like e.g. the physiology of sport (which, as a matter of fact and rightly, is physiology of effort) or the psychology of sport. The latter deals with persons coming from the sports milieu. Psychology is interested also in individuals coming from other milieus - like miners, manual workers, physicians or journalists. It is supposed that it is not a reason for creating such specialized psychologies like the psychology of mining, the psychology of manual work, etc. I mention that in order to point out that there are still problems with constituting and determining qualities of particular disciplines from the field of sports sciences. Even greater problems appear while making attempts at defining the species (and, simultaneously, researchrelated) essence of sports sciences as such. If it is impossible to define sports sciences, their species (and research-related) essence, it is difficult to determine on that basis what the theory of sport - conceived as a derivative, an outcome or a fulguration (Lorenz 1977) of those greatly varied sciences - should deal with.

The philosophy of a given specialised science comes into being - as far as I know - in such a way as it once happened with e.g. the philosophy of physics, mathematics or biology. First a given scientific discipline must come into being and only then its self-knowledge - in the form of the theory of a given discipline - develops. Then, on that basis - that is, as a result of deepening and sublimation of that theory - its philosophy appears (biology, theory of biology and philosophy of biology can serve as an example). Hence, a specialised philosophy becomes a part of a given specialized discipline. Relations between a given specialized discipline, on the one hand, and its specialized methodology and general methodology, on the other hand, are anyway similar. Concluding, we can proclaim that specialized methodologies correspond with general methodology, similarly as specialized philosophies correspond with general philosophy, because that what is general in methodology and philosophy - terms, notions, categories, issues, assumptions - can be used at the initial stage of creation of a specialized methodology or philosophy. However, in philosophy the situation is qualitatively changed and different. Namely, some philosophies of specialized sciences, regardless of their roots and close connections with definite specialized sciences - evolve and become also parts of philosophy as such (like, for example, the philosophy of law, art, religion, etc.). Maybe it will happen also with the philosophy of sport.

In sports sciences there has not appeared yet such a theory which would include assumptions as well as content related and methodological issues being able to constitute a 
common cognitive denominator for all varied scientific disciplines which are connected with them. It even seems that such a situation will never happen. Thus, there will not be fulfilled the first methodological criterion according to Kamiński's interpretation, connected with defining the subject of research, which is so important for establishing autonomy of a scientific discipline.

Regardless of the pessimistic prophecy in that respect, we can surely proclaim that on the ground of sports sciences - unlike in the case of other abovementioned specialized disciplines - there has not appeared their specialized philosophy (that is, a philosophy fulfilling all necessary methodological criteria) yet. That what we have to do with - taking into account the abovementioned viewpoint - can at the best be described as philosophical reflection or considerations on sport, or as elements or aspects of the philosophy of sport at an early stage of development. Nevertheless, taking into account the abovementioned organizationalinstitutional criterion - it can be assumed and maintained that the name the philosophy of sport is justified, because it refers to many varied research disciplines. It is similar in that respect to the philosophy of technology, the philosophy of art or the philosophy of religion.

b) the second reason of the abovementioned immaturity and dependence of the philosophy of sport is lack of necessary research-related competences (the eighth methodological criterion connected with specialized methodology of the discussed discipline is unfulfilled). It refers, on the one hand, to superficial and commonsense character of knowledge on phenomena and issues which are connected with sport - including knowledge in the field of sports sciences, and, on the other hand, to improper preparation, education and philosophical competences. For example, books and papers by Christian (Catholic and Protestant) philosophers proclaiming their opinions about sport (for example, during annual conferences of the Salesian Sports Organisation) prove that their authors are usually excellent experts in a given form of Christian philosophy - what cannot be said about their knowledge on sports issues. The philosophy of sport requires both solid knowledge on philosophy as well as on the theory and practice of sport. If either of them is absent, we will have to do with a philosopher who secondarily tries to become acquainted with sports issues, or with an expert in sport trying to describe and explain theoretical issues which are connected with it with new philosophical cognitive instruments which he does not know very well and cannot master properly. In both cases we would have to do with admittedly ambitious (and, from that viewpoint, praiseworthy) attempt at philosophical reflection on sport, which, however, is not carried out properly. As a result, there appear considerations on the philosophy of sport which surely are neither an autonomous, nor mature form of that philosophy. On the one hand, it is caused by clear shortage of knowledge on sport; on the other, by an amateurish level of philosophical instruments. In the first case, considerations on sport are naive - that is, they are often strikingly incompetent - while in the second we are discouraged from reading them by instrumental shortcomings of the philosophical arguments, which is mainly mediated through handbook schematism and generalities as well as commonsense superficiality.

\section{When will an autonomous and mature form of the philosophy of sport appear?}

A considerable part of the abovementioned views has been presented in a form of a paper during the $33^{\text {rd }}$ Annual Meeting of the International Association for the Philosophy of Sport organised by the Palacky University in Olomouc in September 2005 (the content of the paper is included in the presented text in a corrected and supplemented version). Those who were present during my speech Scott R. Kretchmar, Jim S. Perry, Ivo Jirasek, Arno Muller and others - agreed, to put it mildly, with 
the presented argument. It is proved by a letter which was sent to me by Kretchmar ten days after my presentation. He confirms there, among other things, that I am right proclaiming that the philosophy of sport is only at the beginning of its road, that it is at an early stage of development and that its relations with general philosophy and specialized philosophies are one-sided - that is, the philosophy of sport draws from their achievements striving for its own deepening and development.

Kretchmar's statement is significant because of at least two reasons. Firstly, because he is a recognized authority in the field of the philosophy of sport, both because of his scientific achievements and because of functions connected with the discussed branch which he performed in the past and he performs currently. Secondly - what reveals Kretchmar's magnanimity and scientific objectivism because the most critical part of my speech in Olomouc (and of the currently presented text) referred personally to him - that is, to his works - since it was connected with handbooks on the philosophy of sport. Just those handbooks - including one of the best of them, Practical Philosophy of Sport and Physical Activity (Kretchmar, 2005, 1994) by him - highlight a low cognitive level of the discussed philosophy more than any other publications connected with it. As I have written above, they present the philosophy of sport in a bad light and point out that it is at its initial state of applicative character.

Appearance and development of the philosophy of sport stirs up a question: when can we proclaim that its initial (applicative) period has come to an end, that there has taken place a visible qualitative change in its relations with general philosophy and specialized philosophies and that it has begun to exert inspiring feedback influence on the pointed out philosophies? I am of an opinion that such a clear dividing line is impossible to be pointed out - especially from the viewpoint of here and now. Probably the solution in that respect will be different and only after some decades or later it will be possible to determine when such a fact has taken place.

The situation will be somehow similar to that which took place at the beginning of philosophy as such. It has been discussed who of great sages of ancient Greece can be regarded as the first philosopher. It was assumed that it is Thales from Milesis. However, opinions in that respect are divided, because it sometimes is also assumed that, as a matter of fact, he was a pre-philosophical ancient sage. It is also proved that as the only one of the seven famous sages he manifested philosophical interests. I am of an opinion that his considerations were so superficial and commonsense that they are difficult to be called philosophy and that the first real philosopher was only Anaximander. He inspired Pythagoreans, Parmenides, Plato, Aristotle or indirectly, after over twenty five centuries, Martin Heidegger (Kosiewicz 2006c, pp. 5-25; 2007, pp. 9-22).

Probably there will accidentally appear symptoms, various testimonies to qualitative transformations of the philosophy of sport; assumptions and issues which come solely from it and constitute it, which may inspire and facilitate development of other philosophical branches stimulating for new cognitive endeavours; however, it will not prove existence of the philosophy of sport as such. Then we will have to do - using Hegel's terminology from The Phenomenology of Spirit (Hegel 1963, Kosiewicz 2004f, pp. 5-15; 2006b, pp. 91-101 ) - only with movement towards absolute abstraction. Absolute abstraction - that is coming into being of the philosophy of sport in the full meaning of the word, will take place when those qualitative objectivizations have a permanent - not an accidental character. Only then its development towards maturity can take place.

Each attempt at defining time when the philosophy of sport has appeared will have intuitive, subjective and relative character. It will never be possible to determine it in a precise and empirical way. 


\section{Basic deficiencies and barriers of the philosophy of sport - summary}

Defining organizational-institutional, content related and methodological deficiencies characteristic for the philosophy of sport points out to barriers which must be overcome to enable its further development. It is facilitated by defining its identity.

\section{Institutional-organisational difficulties}

1. The philosophy of sport has not appeared in structures of many scientific and didactic institutions closely connected with sport.

2. Neither she is present in syllabuses and didactic of many of the abovementioned institutions.

3. About $85 \%$ of members the international, the British and the European association of philosophy of sport - as well as participants of conferences on the subject and research projects and teams - have no philosophical education.

4. Many former chairpersons of scientific associations in Europe and outside had no philosophical education. A majority of them played a remarkable organizational and institutional role connected with promoting and strengthening the status of the philosophy of sport. However, their activity only indirectly and insufficiently facilitated development of that philosophy in the content related and methodological sense.

5. The strictly philosophical milieu manifests poor interest in the philosophy of sport. A percentage of persons from that milieu who carry out studies connected with it or express their opinions about it is too low.

\section{Content related and methodological deficiencies}

It is possible to distinguish the following content related and methodological deficiencies characteristic for the philosophy of sport:

1. Shortage of original assumptions and issues, which have been worked out solely on the ground of the philosophy of sport and are characteristic only for that discipline.

2. The discussed philosophy uses only languages of general philosophy and other specialised philosophies, referring to their terms, notions, categories, branches, circles, schools, currents, periods, ages, assumptions, issues, etc.

3. There is no feedback influence on general philosophy and specialised philosophies.

4. Literature on the philosophy of sport has introductory (initial) and applicative qualities.

5. Because of the abovementioned reasons, the philosophy of sport does not meet the fifth, the sixth and the seventh methodological condition concerning becoming independent from the abovementioned application and working out its own, specific assumptions and issues, as well as feedback influence. That is because such a situation makes it impossible to confirm not only its autonomy, but also its maturity.

6. Sports sciences (which, treated in a broader or different way, can be called physical culture sciences) have no common and coherent content related and methodological basis. They are 
very varied in that respect. It makes impossible coherent sublimation of those science in the form of the philosophy of sport. In that case, the first methodological criterion (according to S. Kamiński's interpretation), concerning its autonomy, is not fulfilled, because the subject of its interest connected with sports sciences has not been defined.

7. The fact that the philosophy of sport is not cognitively advanced (that is, there are no significant results of practising it), and that there are no means connected with the discussed activity (that is, a specialised methodology) and facilitating its development, causes that it is neither autonomous, nor mature from the viewpoint of the second methodological criterion according to Kamiński's interpretation.

8. A low level of meta-scientific self-definition of the philosophy of sport causes that the third methodological criterion according to Kamiński's interpretation, concerning self-reliance, is not fulfilled.

9. One of reasons of the abovementioned immaturity and lack of autonomy of the philosophy of sport is also lack of necessary research-related competences (the eighth criterion concerning specialized methodology is not fulfilled). It refers, on the one hand, to superficial and commonsense character of knowledge about phenomena and issues concerning sport including knowledge from the field of sports sciences - and, on the other hand, to improper preparation, education and philosophical competences.

\section{REFERENCES}

Ajdukiewicz, K. (1985). Metodologiczne typy nauk /Methodological Types of Sciences/. In Ajdukiewicz K., Język i poznanie /Language and Cognition/. Warszawa: PWN.

Amsterdamski, S. (1964). Ilość i jakość /Quantity and Quality/. In Amsterdamski, S., Engels. Warszawa: Wiedza Powszechna.

Amsterdamski, S. (1981). Życie naukowe a monopol władzy (casus Łysenko)/Scientific Life and Monopoly of Power (Lysenko's Case)/. Warszawa: Towarzystwo Kursów Naukowych. Wykłady, Wydawnictwo Nowa.

Arnold, J. (1979). Meaning in Movement, Sport and Physical Education. London: Heinemann Education Book Ltd.

Arystoteles (1988). O duszy /On Soul/. Warszawa: PWN.

Bertalanffy, von L. (1973). General System Theory. Foundations, Development, Applications by Ludwig von Bertalanffy. New York.

Bertalanffy, von L. (1984). Ogólna teoria systemu /General System Theory/. Warszawa: PWN.

Best, D. (1978). Philosophy and Human Movement. London: Allen and Unwin.

Carnap, R. (1973). Neopozytywistyczna koncepcja weryfikacji w ujęciu Carnapa /Neo-Positivistic Conception of Verification according to Carnap's Interpretation/. In Mejbaum B., Mejbaum W. (Eds.) Główne zagadnienia filozofii i socjologii marksistowskiej /Main Issues of Marxist Philosophy and Sociology/. Łódź: Wydawnictwo Akademia Medyczna.

Carnap, R. (1969). Sprawdzalność i znaczenie /Testability and Meaning/. In Carnap R., Filozofia jako analiza języka nauki /Philosophy as Analysis of Language of Science/. Warszawa: PWN.

Descartes, R. (1958). Medytacje o pierwszej filozofii /Meditations on First Philosophy/. Warszawa: PWN.

Descartes, R. (1986). Namiętności duszy/Soul's Passion/. Warszawa: PWN.

Domański, J. (1996). Metamorfozy pojęcia filozofii. Od antyku do renesansu /Metamorphoses of the Notion of Philosophy. From Antiquity to Renaissancel. Warszawa: PWN.

Domański, J. (1996). La philosophie, theorie ou maniere de vivre? Les Controverses de l 'Antiquite a la Renaissance, avec une Preface de Piere Hadot. Fribourg-Paris. 
Engels, F. (1953). Dialektyka przyrody /Dialectics of Nature/. Warszawa: Książka i Wiedza.

Engels, F. (1949). Anty-Duhring. Pan Duhring dokonuje przewrotu w nauce /Anti-Duhring/. Warszawa: Książka i Wiedza.

Freud, S. (1982). Wstęp do psychoanalizy /Introduction to Psychoanalysis/. Warszawa: PWN.

Hegel, G.W.F (1963). Fenomenologia ducha /The Phenomenology of Spirit/. Warszawa: PWN.

Heidegger, M. (1994). Bycie i czas /Being and Time/. Warszawa: PWN.

Hobbes, T. (1839). Human Nature. In The English Works of Thomas Hobbes (Ed. W. Molesworth) London.

Hyland, D.A. (1994). Philosophy of Sport. Maryland: University Press of America.

Informator filozofii polskiej /Guidebook of Polish Philosophy/ (2004). Principia XL, Kraków.

Ingenkamp, H.G. (1967). Untersuchungen zu den pseudo-platonischen Definitionen. Wiesbaden.

Journal of the Philosophy of Sport (2006). vol. XXIII, issue 2.

Kamiński, S. (1992). Metoda i nauka. Pojęcie nauki i klasyfikacja nauk /Method and Science. The Notion of Science and Classification of Sciences/. Lublin: KUL.

Kołakowski, L. (2000). Zakresowe i funkcjonalne rozumienie filozofii /Scope-Related and Functional Conception of Philosophy/. In Kołakowski L. Kultura i fetysze /Culture and Fetishes/. Warszawa: PWN.

Kosiewicz, J. (1982). Physical Activity as Reflected by Phenomenology. International Review of Sport Sociology, no. 4.

Kosiewicz, J., Krawczyk, Z., Lipiec, J. (1995). Filozofia sportu czy filozoficzny namysł nad sportem /Philosophy of Sport or Philosophical Reflection on Sport/. Kultura Fizyczna, no. 9-10.

Kosiewicz ,J., Krawczyk, Z. (1997). Philosophy of Sport or Philosophical Reflection over Sport. In Philosophy of Physical Culture. Olomouc: University of Olomouc.

Kosiewicz, J. (1999a). Filozoficzna wykładnia idei olimpizmu /Philosophical Interpretation of the Idea of Olympism/. Edukacja Filozoficzna, no. 27, pp. 340-347.

Kosiewicz, J. (1999b). O idei olimpijskiej filozoficznie /On Olympic Idea in a Philosophical Way/. Literatura, no. 4. p. 59.

Kosiewicz, J. (2004a). Filozofia kultury fizycznej czy filozoficzny namyst nad sportem /Philosophy of Physical Culture or Philosophical Reflection on Sport/. In Filozoficzne aspekty kultury fizycznej i sportu /Philosophical Aspects of Physical Culture and Sport/. Warszawa: Wydawnictwo BK.

Kosiewicz, J. (2004b). Sport i powszechniki - od nominalizmu do aleatoryzmu /Sport and Universals - from Nominalism to Aleatorism. In Filozoficzne aspekty kultury fizycznej i sportu /Phylosophical Aspects of Physical Culture ans Sport/. Warszawa: Wydawnictwo BK.

Kosiewicz, J. (2004c). The Universals of Sport-from Realism to Nominalism. In Philosophy of Sport and Other Essays (eds. Macura D., Hosta M.). Ljubljana: Faculty of Sport, University of Ljubljana.

Kosiewicz, J. (2004d). Struktura widowiska sportowego /Structure of Sports Spectacle/. In Filozoficzne aspekty kultury fizycznej i sportu /Philosophical Aspects of Physical Culture and Sport/. Warszawa: Wydawnictwo BK.

Kosiewicz, J. (2004e). Widowisko sportowe w świetle założeń aleatoryzmu - stałe i przypadkowe elementy struktury spektaklu /Sports Spectacle in the Light of Assumptions of Aleatorism - Constant and Accidental Elements of Its Structure/. In Kosiewicz J. Filozoficzne aspekty kultury fizycznej i sportu /Philosophical Aspects of Physical Culture and Sport/. Warszawa: Wydawnictwo BK.

Kosiewicz, J. (2004f). Hegel - człowiek jako niezbędne centralne ogniwo w procesie samorealizacji Absolutu /Hegel - Man as the Necessary Central Link in the Process of Self-Realisation of the Absolute/. Roczniki Naukowe AWF vol. XLII, Warszawa.

Kosiewicz, J. (2005a). Sport in the Reflection of Philosophy. Research Yearbook. Studies in Physical Education and Sport, Vol. 11, Gdańsk.

Kosiewicz ,J. (2005b). Philosophy of Sport or Philosophical Reflection on Sport. Acta Facultatis Educatonis Physicae Universitatis Comenianae. t. XLVI, Bratysława. 
Kosiewicz, J. (2006a). Filozofia sportu czy filozoficzny namysł nad sportem - nowe ujęcie /Philosophy of Sport or Philosophical Reflection on Sport - a New Interpretation/. Idŏ. Ruch dla Kultury, t. VI.

Kosiewicz, J. (2006b). Boxing Fight as a Manifestation of Movement Towards Absolute Abstraction. Moving Body, Norges IdrettsHogskole.

Kosiewicz, J. (2006c). Czas wolny w perspektywie epistemologii i ontologii czasu /Free Time from the Perspective of Ontology and Epistemology of Time/. Roczniki Naukowe AWF, vol. VLIV.

Kosiewicz, J. (2007). Free Time from the Perspective of Ontology and Epistemology of Time. In Socio-economic Aspects of Tourism and Recreation, Dąbrowski, A., Rowiński, R. (Eds.). Warsaw: AWF.

Krawczyk, Z., Kosiewicz, J. (1990). Filozofia kultury fizycznej. Koncepcje i problemy /Philosophy of Physical Culture. Conceptions and Problems/. Warszawa: AWF.

Krawczyk, Z., Kosiewicz, J. (1997). Refleksje o filozofii sportu /Reflections on the Philosophy of Sport/. In Dziubiński Z. (Ed.) Teologia i filozofia sportu /Theology and Philosophy of Sport/. Warszawa: SALOS.

Kowalczyk, S. (2002). Elementy filozofii i teologii sportu /Elements of Philosophy and Theology of Sport/. Lublin: KUL.

Kowalczyk, S. (2007). Czy istnieje filozofia sportu? /Does the Philosophy of Sport Exist?/ Idŏ. Ruch dla Kultury, vol. VII.

Kraszewski, Z. (1975). O sporach naukowych /On Scientific Disputes/. In Kraszewski Z. Logika, nauka rozumowania /Logic, Learning to Reason/. Warszawa: KUL.

Kretchmar, R.S. (1994). Practical Philosophy of Sport. Illinois: Human Kinetics.

Kretchmar, R.S. (2005). Practical Philosophy of Sport and Physical Activity. Champaign USA: Human Kinetics.

Krokiewicz, A. (1995). Zarys filozofii greckiej. Od Talesa do Platona. Arystoteles, Pirron i Plotyn /An Outline of Greek Philosophy. From Thales to Plato. Aristotle, Pirron and Plotinus. Warszawa: Aletheia.

Kuczyński, J. (1990). Gra jako negacja i tworzenie świata /Game as Negation and Creation of the World/. In Krawczyk Z., Kosiewicz J. (Eds.) Filozofia kultury fizycznej. Koncepcje i problemy /Philosophy of Physical Culture. Conceptions and Problems/. vol. 2. Warszawa: AWF.

Lenk, H. (1969). Social Philosophy of Athletic. Illinois: Stipes Publishing.

Lenk, H. (Ed.). (1983). Topical of Sport. Schorndorf: Velag Karl Hoffman.

Lenk, H. (1982). Prolegomena Toward an Analytic Philosophy of Sport. International Journal of Physical Education, 19 p. 15.

Lenk, H. (1988). Towards a Social Philosophy of Achievement and Athletic, In Morgan, W.J. and Meier, K.V. (Eds.), Philosophic inquiry in sport. Champaign: Human Kinetics Publishers.

Lipiec, J. (1999). Filozofia olimpizmu/Philosophy of Olympism/. Warszawa: Wydawnictwo Sportowe SPRINT.

Lorenz, K. (1977). Odwrotna strona zwierciadta. Próba historii naturalnej ludzkiego poznania /The Reverse Side of the Mirror - an Attempted Natural History of Human Cognition/. Warszawa: PIW.

McFee, G. (1998). Are There Philosophical Issues Respect to sport (Other than Ethical Ones). In Ethics and Sport (Ed. by McNamee M., Perry S.J.). London and New York: Spon Press, Taylor \& Francis Group.

McFee, G. (2006). Searching for Truth in Sport and Exercise Sciences. European Journal of Sport Science, Vol. 6, no 1. Taylor and Francis Ltd.

McFee, G. (2007). Paradigms and Possibilities: Or, Some Concerns for the Study of Sport from the Philosophy of Science. Sport, Ethics and Philosophy. Official Journal of the British Philosophy of Sport Association, Vol. 1, no 1. Routledge, Taylor and Francis Group.

Misiuna, B., Przyłuska-Fiszer, A. (1993). Etyczne aspekty sportu /Ethical Aspects of Sport/. Warszawa: AWF.

La Mettrie, J. O. de (1748). L'homme machine.

La Mettrie, J. O. De (1984). Człowiek - maszyna /Man - Machine/. Warszawa: PWN.

Pomponazzi, O. (1980). O nieśmiertelności duszy /On Immortality of the Soull. Warszawa: PWN.

Pseudo-Platon (1973). Alkibiades i inne dialogi oraz Definicje /Alkibiades and Other Dialogues. Definitions/. Warszawa: PWN. 
Read, H. (2007). Sport as Philosophy. Presidential Address to the IAPS 2007. Unpublished. An address delivered during the conference of the IAPS in Ljubljana in 2007.

Religia /Religion/ (2002). vol. 6, Warszawa: PWN.

Sartre, J.-P. (1956). Being and Nothingness: An Essay on Phenomenological Ontology. Philosophical Library.

Sartre, J.-P. (1943). L'etre le neant: Essai d'ontologie phenomenologique. Paris: Galimard.

Skwarczyńska, S. (1978). Wspótczesna teoria literatury /Contemporary Theory of Literature/. Warszawa: PWN.

Slusher, H.S. (1967). Man, Sport and Existence: Critical Analysis. Philadelphia: Lea and Febiger.

Suits, B. (1978). The Grasshopper; Life and Utopia. Toronto: University of Toronto Press.

Thomas, E. C. (1983). Sport in a Philosophic Context. Philadelphia: Lea and Febiger.

Wójcicki, R. (1982). Cztery rodzaje zagadnień metodologicznych /Four Kinds of Methodological Issues/. In Wójcicki R., Wykłady z metodologii nauk. Warszawa: PWN. 